\title{
Fungus gnats (Diptera: Sciaroidea) associated with dead wood and wood growing fungi: new rearing data from Finland and Russian Karelia and general analysis of known larval microhabitats in Europe
}

\author{
Jevgeni Jakovlev
}

Jakovlev, J. 2011: Fungus gnats (Diptera: Sciaroidea) associated with dead wood and wood growing fungi: new rearing data from Finland and Russian Karelia and general analysis of known larval microhabitats in Europe. - Entomol. Fennica 22: $157-189$.

In this contribution new rearing records of fungus gnats from poorly studied larval microhabitats are presented. From 61 species of wood growing Basidiomycete fungi, 6 species of Ascomycete fungi and slime moulds most of which had not previously been the subject of rearing studies, and from dead wood samples with fungal mycelia made over a period of 1994-2009 in Finland and Russian Karelia, 110 species of fungus gnats were obtained, 98 of them from identified fungi. Of these for 12 species fungal hosts were formerly unknown and for 30 species larval microhabitats have been discovered for the first time. Numbers of fungus gnat species with known larval microhabitats (a total of 498 species that comprises $45.4 \%$ of the European fauna) and numbers of known fungal hosts (some 650 species of macrofungi) are calculated and categorized based on this study and previous records from Europe and East Palaearctic.

J. Jakovlev, Finnish Forest Research Institute, Vantaa Research Unit, P.O. Box 18, FI-01301 Vantaa, Finland; E-mail: jevgeni.jakovlev@metla.fi

Received 14 July 2010, accepted 5 November 2010

\section{Introduction}

Diptera are one of the major groups of saproxylic insects, but the ecology of most species is still poorly known. Many species are rare and threatened with extinction due to loss of woodlands and impoverishment of what remains. However, the conservation of them is hindered by lack of knowledge, particularly poor understanding of the larval habitat requirements (Rotheray et al. 2001). During recent years many studies of substrate associations among insects inhabiting dead wood and fungi growing on wood have been made, but with a few exceptions they do not con- cern Diptera. This is due in part to the technical difficulties of obtaining adult flies from larvae living in fungal fruiting bodies, and especially in decaying wood, which are most difficult to be cultured. Not least is the problem of identifying host fungi, especially if they are present in the samples only as sterile tissues (mycelia) that are often used by Diptera larvae.

Fungus gnats in the broad sense (Diptera: Sciaroidea without Sciaridae), including the families Bolitophilidae, Ditomyiidae, Diadocidiidae, Keroplatidae, and Mycetophilidae with more than 1,100 species that occur in Europe (Chandler 2004 and subsequent contributions by various au- 
thors) comprise the largest group of Diptera associated with fungi. All known rearing records of fungus gnats with a few exceptions are from fungi, either from fruiting bodies or from rotten wood or soil litter impregnated with fungal mycelia. Based on this fungus gnat larvae are generally viewed as mycetophagous although it is uncertain how many species are true fungal feeders and how many are predatory or saprophagous.

Studies focused on discovering fungal host species of the larvae of fungus gnats has a long history in Europe. Traditionally good knowledge of the larval microhabitats have been in Great Britain since a classic study by Edwards (1925) and subsequent investigations by Madwar (1937), Buxton (1960), Trifourkis (1977) and Chandler (1978, 1993a) covering about two hundred fungus gnat species. Comprehensive studies on Diptera living as larvae in fungi were conducted also in certain areas of Central Europe, e.g. German and Austrian Alps (Eisfelder 1955, Plassmann 1971), Hungary (Dely-Draskovits 1974), Czech \& Slovak republics (Ševčik 2006) and in Northern Europe, including Finland (Hackman \& Meinander 1979, Väisänen 1981), Russian Karelia (Jakovlev 1980, 1986, 1995) and Estonia (Kurina 1991, 1994, 1998).

Rearing records of fungus gnats were also obtained from France (Falcoz 1921, 1923, 1926, Bonnamour 1926, Matile 1962, 1963, 1964, 1990), the Netherlands (Barendrecht 1938), Italy (Canzanelli 1941), Bulgaria (Bechev 1989), Portugal (Ribeiro 1990), Lithuania (Rimšaite 2000) and some areas of Central Russia (Sakharova 1977, Zaitzev 1984c, Khalidov 1984, Krivosheina et al. 1986), Southern Russia and Transcaucasian republics (Krivosheina \& Mamajev 1968, Zaitzev 1994, 2003), Siberia and Russian Far East (Ostroverkhova 1979, Zaitzev 1982, 1994, 2003) and Japan (Okada 1939, Sasakawa \& Ishizaki 1999).

According to my compilation classifying the present knowledge of rearing records of Palaearctic Diptera from fungal fruiting bodies and from other media containing fungal hyphae (Jakovlev 1994), identified fungal hosts were known for some 300 species in the Palaearctic Region and some 280 species in Europe, of these some old rearing records which cannot be checked by studying the collected material need confirmation (Falk \& Chandler 2005). In more recent years additional rearing records were obtained from Europe by Chandler (1993a), Rimšaite (2000), Zaitzev (2003), Ševčik (2006) and from Japan (Sasakawa \& Ishitaki 1999), which raised the total number of fungus gnat species with known larval microhabitats to some 400 species in Palaearctic and some 380 species in Europe.

A further increase in sources of information on fungus gnat species with formerly unknown larval microhabitats appeared when researchers started to use emergence traps set up on dead wood (over fallen trunks, branches and stumps), soil, litter and moss carpets (Jakovlev et al. 1994, Irmler et al. 1996, Økland 1999, Ševčík \& Roháček 2008; Jakovlev, J., Penttinen, J., Polevoi, A., Salmela, J. \& Ståhls-Mäkelä, G., in prep.). This method does not alter the substrate or microclimatic conditions and certainly produces a considerable variety of fungus gnat species. However, records obtained by the emergence traps (with a few exceptions, e.g. Cardew \& Carrières (2001) where the authors sampled only one fungal species) do not always provide the exact information on the fungal hosts because two or more species of fungi might inhabit the sample covered with the trap. This does not allow correlating hatched species of insects with their respective fungal hosts, and the records are not of the same value as those obtained with rearing from the sample of only one host fungus which is correctly identified.

Current knowledge of the host fungi of fungus gnat species relies mostly upon rearing records from soft fruiting bodies of agarics, russulas, boleti and some soft polypores, whereas associations with wood-encrusting fungi and with fungal mycelia in dead wood, soil and litter are still poorly investigated. What little is known of saproxylic mycetophilids has been summarized for the British Isles by Alexander (2002), chiefly on the basis of the accounts of Edwards (1925) and Chandler (1978, 1993a). For other areas of the Palaearctic region rearing records from woodencrusting fungi and slime moulds are scattered in a few publications of which the most comprehensive are Krivosheina et al. (1986), Jakovlev (1994), Zaitzev (1994, 2003) and Ševčik (2006).

It is evident that a requirement is a study of the 
Table 1. List of study sites with information on their location and forest type. The locality name is the closest name for each site on a 1:20 000 map. The following abbreviations are used for the site types: ogf $=$ old growth forest, $\mathrm{omf}=$ old managed forest, city $=$ urban forest patches in cities; $b c c=$ clear-cut treated with prescribed burning. Coordinates: Finland = E27 grid; Russian Karelia = E33 grid.

\begin{tabular}{|c|c|c|c|c|c|c|}
\hline $\begin{array}{l}\text { Site } \\
\text { No }\end{array}$ & $\begin{array}{l}\text { Pro- } \\
\text { vince }\end{array}$ & Municipality & Locality & Coordinates & Site type & Years \\
\hline 1 & $A b$ & Karjalohja & Karkali SNR & $66851: 33221$ & ogf, lime & 2004-2008 \\
\hline 2 & $\mathrm{~N}$ & Espoo & Nuuksio SNR & 66939:33621 & ogf, spruce & 2005 \\
\hline 3 & $\mathrm{Ta}$ & Lammi & Kotinen SNR & 67944:33964 & ogf, aspen & 2004-2008 \\
\hline 4 & $\mathrm{Ta}$ & Lammi & Kotinen SNR & 67946:33965 & ogf, spruce & 2003 \\
\hline 5 & $\mathrm{Ta}$ & Padasjoki & Vesijako SNR & 68061:33988 & ogf, spruce & 2005,2008 \\
\hline 6 & $P p$ & Tervola & Pisavaara SNR & $73536: 34154$ & ogf, spruce & 2003 \\
\hline 7 & Kon & Kondopoga & Kivach SNR & 69088:35503 & ogf, spruce & $1994,1998,2000$ \\
\hline $8 a$ & Ok & Kuhmo & Ulvinsalo SNR & 70998:36638 & ogf, spruce & 2004,2005 \\
\hline $8 b$ & Ok & Kuhmo & Paljakka SNR & 71834:35502 & ogf, spruce & 2004,2005 \\
\hline $8 c$ & Kpoc & Kostomuksha & Kostamus SNR & 71707:36590 & ogf, spruce & 2005 \\
\hline 9 & $N$ & Sipoo & Rörstrånd & 67068:34008 & ogf, spruce & 2005, 2009 \\
\hline 10 & $N$ & Sipoo & Sipoonkorpi & $66915: 33983$ & ogf, spruce & 2008, 2009 \\
\hline 11 & $N$ & Kirkkonummi & Fagerö & 66694:33661 & omf, alder & 2007 \\
\hline 12 & $\mathrm{Ta}$ & Lammi & Pappilanlehto & 67731:33946 & omf, aspen & $2004,2007,2008$ \\
\hline 13 & $\mathrm{Ta}$ & Luopioinen & Kuohijoki & $68017: 33813$ & omf, aspen & 2007,2008 \\
\hline 14 & $N$ & Helsinki & Haltiala & 66859:33855 & city, spruce & 2007,2008 \\
\hline 15 & $N$ & Helsinki & Herttoniemi & 66801:33909 & city, spruce & 2007 \\
\hline 16 & $N$ & Vantaa & Kuusijärvi & 66909:33962 & city, spruce & $2001,2003,2004$ \\
\hline 17 & $N$ & Tuusula, & Ruotsinkylä & 66971:33898 & city, spruce & 2005 \\
\hline 18 & Kon & Petrozavodsk & Lososinka & 68519:35571 & city, spruce & 1996 \\
\hline 19 & $\mathrm{Li}$ & Kilpisjärvi & Saana mountain & $76751: 32533$ & mountain birch & 2006 \\
\hline 20 & $\mathrm{Ta}$ & Lammi & Evo, Leipäsuonaho & 67899:33959 & bcc & $2003,2005,2008$ \\
\hline 21 & $\mathrm{Ta}$ & Lammi & Evo, Saarijärvi & 67927:33959 & bcc & $2003,2004,2005$ \\
\hline
\end{tabular}

fungus gnat species which might be reared from a wide range of wood-growing fungi that have not been sufficiently examined by entomologists. Many species with unknown larval microhabitats could be restricted to species or to groups of fungi that have been little studied. The other option is that they do not colonize fruiting bodies but use decaying wood as a shelter and fungal mycelia as nutrition that make them difficult to find and rear.

For the past fifteen years I have worked to fill this gap in knowledge and this paper presents results of my rearing experiments from dead wood and wood-encrusting fungi in Finland and Russian Karelia that have not been published yet. Most of the fungi involved had not previously been the subject of rearing studies. I also tried to summarize all rearing records from the literature to categorise substrate associations of fungus gnat species occurring in Europe.

\section{Study areas, material and methods}

\subsection{Sampling sites}

The data presented in this paper result from materials collected in Russian Karelia during 1994 2000 and in Finland during 2001-2009. The study areas were located both in hemiboreal, southern-, mid- and northern boreal zones and according to Heikinheimo \& Raatikainen (1971), include biogeographical provinces of Regio aboensis (Ab), Nylandia ( $N)$, Tavastia australis, (Ta), Ostrobottnia kajanensis (Ok), Ostrobottnia borealis $(\mathrm{Ob})$, Lapponia enontekiensis (Le) in Finland, Karelia onegensis (Kon) and Karelia pomorica occidentalis (Kpoc) in Russian Karelia.

The sites from which fungi were sampled (Table 1) were selected to obtain a diversity of wood-growing fungi and were, therefore, generally situated in protected areas where fallen wood is left to decay on the ground. Altogether ten sites 
consisted of old-growth forest (ogf) in strict nature reserves (SNR) in Finland (sites 1-6, 8a, b) and in Russian Karelia (sites 7, 8c). Another ten sites (10-18) were in small reserves for oldgrowth (sites 9-10), old-managed forest (omf, sites 11-13) and urban forest patches (city) preserved within the cities of Helsinki (sites 14-15), Vantaa, Tuusula (sites 16-17) and Petrozavodsk (site 18). All these sites represent seminatural coniferous forest, whether spruce-dominated or mixed herb-rich forest on the limestone and fertile soils with a large proportion of deciduous trees, chiefly aspen, birch, alder, and in some sites also lime and hazel.

Additional rearing records were obtained from non-forested sites like oroarctic mountain birch meadows behind the timberline in Finnish Lapland (site 19) and, to allow fire-dependent fungi to be sampled, from clear cuts treated with prescribed burning (bcc) in 1997-2001 and with some trees retained, in southern Finland (sites 20-21).

\subsection{Sampling methods}

Adult fungus gnats were reared from fruiting bodies growing on dead wood or from pieces of dead wood impregnated with fungal mycelium. I aimed to cover a wide range of wood-decay fungi and therefore tried to check different tree species in different stages of decay (including strongly decayed logs overgrown by surrounding ground vegetation) and in different conditions. The study areas were walked through and dead wood appearing to be suitable habitat for fungus gnat larvae (fallen logs, logging residues and naturally broken branches, stumps and standing dead trees) were carefully examined. Mosses, lichens and liverworts growing on decaying wood were also examined for the presence of Diptera larvae. Samples containing larvae were taken for further rearing. The common species of fungi (e.g. Fomes fomentarius, Fomitopsis pinicola, etc.) were identified directly in the field, but of the more difficult species I collected specimens of fruiting bodies for further microscopical identification by the experts (see Acknowledgements).

A few specimens of Mycetophilidae collected during an investigation into the saproxylic insects in Kuhmo, Eastern Finland and Kostamus Strict Nature Reserve, Russian Karelia were passed to me by Gergely Várkonyi in 2004-2005 and those reared from fruiting bodies of polypores in Pisavaara, northern Finland that I obtained from Dmitry Schigel in 2004 are also included in this paper.

\subsection{Rearing techniques}

In 1994-2007 for rearing adult flies from fungal hosts I used the traditional method by placing the sample of fungal fruiting bodies or pieces of dead wood with mycetophilid larvae into rearing chambers on a layer of sterilized peat soil (turf). A peat (substrate) was covered with damp moss (Sphagnum, etc.) on which the samples were placed. To minimize disturbance of the larval webs I tried to sample relatively big pieces of decaying wood with fungi using $1.5-21$ plastic containers (sizes vary from $114 \times 110 \mathrm{~mm}$ to $180 \times$ $180 \mathrm{~mm}$ ) as the rearing chambers. The containers were kept outdoors until the first frost in October - November, and then were removed to the laboratory where the rearing process was continued at room temperature. The containers were regularly checked to collect emerging adults, keeping moisture and removing moulds, predaceous beetles and mites.

In 2008-2009 to avoid high mortality of larvae the rearing techniques were slightly modified: a part of the rearing chambers were moved into the laboratory, while the other part was operated directly in the forest sites to provide the larvae with a more natural pupation habitat. Samples were sorted in two parts by the kinds of material: (1) larvae inside fungal fruiting bodies or (2) outside fruiting bodies, or in/on wood, under bark, etc. For the latter group of samples I removed the bottoms from the plastic containers and embedded them flush with the soil directly in the forest site, next to the log or stump where the larvae were found. Then I put the sample with larvae within the container on a layer of damp moss. Containers were covered with a perforated transparent cover and protected from rain with a kind of hip-roof made from laminated paper. I checked the containers one-two times a month during the season, opening the cover and placing inside a 
small piece of cotton with ether for a short time. Then I carefully searched emerging adults with a pocket lamp. Adult fungus gnats that emerged in the rearing chambers were identified to the species level (all males and also the females in some genera where it was possible) and preserved in $70 \%$ alcohol using $2 \mathrm{ml}$ plastic tubes with screw caps. Male terminalia for detailed observation were separated from the abdomen and heated in a solution of $\mathrm{KOH}$ for maceration, then washed with acetic acid and distilled water for neutralization and inserted into glycerine. After examination, terminalia were stored in the glycerine medium in special plastic microvials. The material is deposited in the author's collection.

\section{Results}

The pooled material obtained during this study consists of more than 400 reared individuals and 110 species of mycetophilids, 98 of them from identified fungi, the others from rotten wood without fungal fruiting bodies. They were reared from 61 species of Basidiomycete fungi, including agarics, polypores and non-polypore species, 5 species of Ascomycete fungi and one species of slime moulds (see Appendix).

Among 110 fungus gnat species listed in this paper 68 species have previously been reared from fungi. For the other 12 species, viz.: Diadocidia spinosula, Orfelia nigricornis, O. unicolor, Macrocera fasciata, M. pilosa, Mycomya bicolour, Boletina nigricans, Ectrepesthoneura colyeri, Dynatosoma reciprocum, Trichonta hamata, T. subfusca, T. subterminalis fungal hosts were unknown and for 30 species, including Orfelia nemoralis, Mycomya nitida, M. forestaria, M. ruficollis, Neoempheria pictipennis, Boletina edwardsi, B. populina, Acnemia falcata, Phthinia congenita, P. mira, Sciophila fenestella, S. jakutica, S. setosa, Syntemna daisetsuzana, S. penicilla, S. stylatoides, Leia picta, Epicypta fumigata, Mycetophila abiecta, M. bohemica, M. dziedzickii, M. lubomirskii, M. xanthopyga, Phronia unica, Zygomyia pictipennis, Z. vara, Z. zaitzevi, Brevicornu serenum, Exechiopsis pulchella and Pseudobrachypeza helvetica larval microhabitats were discovered for the first time.

\subsection{Survey of species}

The list of fungus gnat species obtained during this study is constructed in the following order: species name, number of reared individuals (males, females), locality according to Table 1, species of fungus (if fungus fruiting body present in the sample), tree species and details (trunk, stump, branch), collecting date, emergence date. Larvae and cocoons, if not specified otherwise, were found in/on the fruiting body. Fruiting bodies collected from the same tree are considered as one sample

Species with formerly unknown named fungal hosts are marked with one asterisk $(*)$ in front of the species name, those with totally unknown larval microhabitats (the first rearing records) are marked with two asterisks $(* *)$. Specimens obtained from D. Schigel and G. Várkonyi are denoted with the collector's name within brackets, otherwise all material was collected by the author.

Higher taxonomy of mycetophilids follows Bechev (2000), hierarchy and numbers of species occurring in Europe are given, if not specified otherwise, according to the Fauna Europaea online database (Chandler 2004). The nomenclature of fungi generally follows CABI, Bioscience databases (2008) and Kotiranta et al. (2009) for polypores and other aphyllophoroid fungi.

Data on known larval microhabitats is presented (if the original record is not otherwise specified) according to Jakovlev (1994) and further rearing records from fungal fruiting bodies by Chandler (1993a), Kurina (1998), Rimšaite (2000), Zaitzev (2003) and Ševčík (2006). Records obtained with emergence traps over decaying wood, soil and leaf litter (Jakovlev et al. 1994, Irmler et al. 1996, Økland 1999, Ševčík \& Roháček 2008; Jakovlev, J., Penttinen, J., Polevoi, A., Salmela, J. \& Ståhls-Mäkelä, G., in prep.) are indicated separately.

\subsubsection{Family Bolitophilidae}

\section{Genus Bolitophila Meigen}

Bolitophila is a genus comprising 36 species In Europe, of these there are rearing records for twenty one species, all from fungal fruiting bodies. Most species are associated with Agaricales 
(both lignicolous and terrestrial) and Boletales. Of these there are some polyphagous species (e.g. $B$. cinerea Meigen, 1818, B. tenella Winnertz, 1863, B. hybrida Meigen, 1804, B. pseudohybrida, Landrock 1912) that were reared from a number of fungal hosts and, vice versa, species that are probably confined to particular group of fungal hosts, e.g. B. basicornis Mayer, 1871 fungi of the family Cortinariaceae, B. apertaStrophariaceae, B. bimaculata Zetterstedt, 1838, B. glabrata Loew, 1869 and B. maculipennis Walker, 1836 - Tricholomataceae, $B$. nigrolineata Landrock, 1912 - Paxillaceae, B. rossica Landrock, 1912 - Boletaceae. Among wood-growing fungi Bolitophila species usually colonize agarics like Armillaria, Flammulina, Hypholoma and Pholiota. Only three species: $B$. occlusa Edwards, 1913, B. obscurior Stackelberg, 1969 and $B$. rectangulata Lundström, 1913 are chiefly or exclusively associated with soft polypores, of these $B$. rectangulata is restricted to the only fungal hosts, Laetiporus sulphureus.

Bolitophila (Bolitophila) tenella Winnertz, 1863. 4 ठึ. Site 5, ex. Armillaria mellea-group on aspen, 18.VIII.-4.IX.2003. Formerly reared from many species of agarics, mostly woodgrowing Armillaria, Hypholoma and Pholiota.

Bolitophila (Cliopisa) aperta Lundström, 1915. 7 ふึฎ, 3 우, Site 12, ex. Pholiota squarro$s a$ on birch, 24.IX.-1.XI.2007; 2 ふえ,, Site 15, ex. Hypholoma capnoides on spruce stump, 2.IX.13.X.2008. Formerly has been reared from Hypholoma capnoides (Hackman \& Meinander 1979), H. fasciculare, Cortinarius trivialis and Tricholoma focale (Jakovlev 1995), all rearing records were obtained from Finland and Russian Karelia.

Bolitophila (Cliopisa) occlusa Edwards, 1913. 5 तै $\hat{\jmath}, 4$ 우, Site 10, ex. Postia alni on aspen stump on clear-cut, 4.-18.IX. and 22.IX. 2008; 2 $\widehat{\jmath}, 1$ \&, Site 5, ex Postia caesia on spruce log, 24.VIII.-25.IX.2008; 5 ठึ $\widehat{\jmath}, 4$ 우, Site 9, ex. Postia stiptica on spruce log, 19.X.-5.XI.

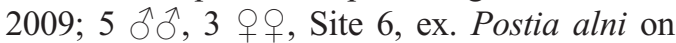
aspen $\log$ (D. Schigel leg ); 2 ふ઼, same place ex. Leptoporus mollis on spruce log (D.Schigel leg.). Formerly has been reared from Hypholoma fasciculare (Bogatyreva 1979), Pleurotus (Zaitzev 1984c) and from small soft polypores as Polyporus (Ostroverkhova 1979), Amylocystis (Komo- nen 2001), Postia and Leptoporus (Chandler 1978, Ševčík 2006, Schigel et al. 2006).

\subsubsection{Family Diadocidiidae}

Genus Diadocidia Ruthe

Five species in Europe; collecting records obtained using emergence traps over rotting wood exist for the three most common ones: $D$. ferruginosa Meigen, 1830, D. valida Mik, 1874, D. spinosula Tollet, 1948 (Irmler et al. 1996, Økland 1999) and for the recently described species D. trispinosa Polevoi, 1995 (Jakovlev, J., Penttinen, J., Polevoi, A., Salmela, J. \& StåhlsMäkelä, G., in prep.). Preimaginal stages are described only for $D$. ferruginosa that live as larvae in long dry silken tubes under bark or in rotten wood (Edwards 1925) and probably feed on fungal mycelia (Zaitzev 1994) or spores (Matile 1997).

Diadocidia ferruginosa Meigen, 1830. 1 ô, Site 18, ex. Peniophora laurentii on fallen pine branch, 12.-29.VI.1996. Chandler (1993a) reported the rearing of this species from the fungus Peniophora sp.

* Diadocidia spinosula Tollet, 1948. 3 ふ઼ô, Site 18. Reared from decaying wood of burnt spruce stump bearing Antrodia xantha, 12.29.VI.1996.

\subsubsection{Family Keroplatidae}

Subfamily Keroplatinae

Genus Keroplatus Bosc

All five species occuring in Europe are web spinners on bracket fungi and probably spore feeders (Matile 1990). Larvae of the most widespread species, K. testaceus Dalman, 1818 and K. tipuloides Bosc, 1792 have been repeatedly recorded living in webs, which they construct under the brackets and on adjacent bark (Chandler 1993b, Jakovlev 1994). K. reaumurii Dufour, 1839 was reared by Chandler (1993b) from larvae found on undetermined encrusting fungi on fallen branches. Ševčík (2006) reared K. tuvensis Zaitzev, 1991 from Polyporus varius. Accociations with Thelephora terrestris for K. dispar Dufour, 1839 cited in Jakovlev (1994) actually related to K. testaceus. 
Keroplatus testaceus Dalman, 1818.1 ऽ̋, Site 17, ex. Trametes hirsuta on birch log, 10.VI.5.VII.2002; 1 ð, 2 우, Site 2, ex Bjerkandera adusta on dead standing grey alder, 10.VIII.9.X.2005; 2 ठิ 1 , 1 , Site 2, ex Fomitopsis pinicola on fallen grey alder log, 16.VI.-

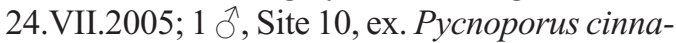
barinus on birch log, 14.V.-12.VII.2008. This species develops in webs on the underside of logs bearing encrusting fungi or beneath the brackets of polypores. There are records from Fomes, Fomitopsis, Hapalopilus, Phellinus, Polyporus, Pycnoporus, Stereum, Serpula and Trametes species (Falk \& Chandler 2005).

Keroplatus tipuloides Bosc, 1792.1 ㅅ, 2 우, Site 4, ex. Fomes fomentarius on birch, 9.VI.12.VII.2003. Formerly was reared repeatedly from $F$. fomentarius and was, therefore, classified as monophagous on this fungal host (Jakovlev 1994, Cardew \& Carrières 2001).

\section{Genus Orfelia Costa}

Fifteen species in Europe, all are web spinners chiefly associated with dead wood but, according to Hutson et al. (1980) and Smith (1989) could be also found in turf, grass tussocks, under logs and boulders, in worm tunnels, among mosses and liverworts. Rearing records do not indicate named fungal hosts with the exception of Chandler (1993a) who has reported Orfelia unicolor for the first time from the pupa suspended in threads on Trametes versicolor.

* Orfelia fasciata (Meigen, 1804). 1 ふ઼, Site 13 , reared from damp aspen stump; the larva in webs under the loose bark bearing dead sporophores of Trametes ochracea, 29.V.-18.VII. 2008. Formerly was reared by Edwards (1925, p.530) from "larvae found feeding on moulds under loose but wet bark (poplar)" and obtained in emergence traps over beech stumps, logs and on litter (Irmler et al. 1996).

** Orfelia nemoralis (Meigen, 1818). 1 ऽ, Site 13, reared from slash residues in aspen-dominated forest. Larvae in webs on the underside of fallen damp aspen branches bearing fungal mycelium and resupinate fruiting bodies of Byssomerulius corium, 29.V.-18.VII.2008. No former rearing records.

*Orfelia nigricornis Fabricius 1805. 2 ๙ぇ, Site 13, reared from slash residues in aspen-domi- nated forest. Larvae in webs on the underside of fallen damp aspen branches bearing fungal mycelium and resupinate fruiting bodies of Byssomerulius corium, 29.V.-18.VII.2008; 1 के, Site 8a, reared from a piece of decaying aspen log, 9.-16.VII.2004 (G.Várkonyi et al. leg). Formerly larvae were found in rotting wood (Chandler 1978), under bark of dead trunk of Juglans regia (Zaitzev 1994) and imago obtained with emergence traps over beech logs (Irmler et al. 1996).

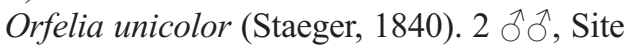
1 , reared from fallen moist and moss-covered trunk of willow, Salix caprea. Larvae in webs on lower side, on the surface of rotten wood without fungal fruiting bodies. 26.V.-30.VII.2006. Formerly reared from fallen spruce trunk, larvae under bark, on the surface of dead wood covered with fungal mycelia (Zaitzev 1994) and obtained in emergence traps over beech and alder logs (Irmler et al. 1996).

\section{Genus Neoplatyura Malloch}

Four species in Europe, rearing records exist for only one species, $N$. flava, larval habits are similar to those of Orfelia - the larvae live in webs under bark, under fallen wood and in soil.

Neoplatyura flava (Macquart, 1826). 1 ô, Site 10, reared from damp moist birch branches stored in heaps at the edge of clear-cut area. 29.V.-18.VI.2007. The larva in webs on the underside of branches bearing dead fruiting bodies of Fomes fomentarius. Formerly was obtained with emergence traps over decaying pine wood (Jakovlev et al. 1994) on soil, ground vegetation and moss carpets (Økland 1999) and has been reared in West Siberia from Daldinia concentrica and Chalciporus piperatus (Bogatyreva 1979).

\section{Subfamily Macrocerinae}

\section{Genus Macrocera Meigen.}

This genus contains 46 species in Europe. In contrast with Keroplatinae, larvae of Macrocera are quite difficult to find and that seems to be the reason of the total absence of rearing records from named fungal hosts. Edwards (1925) mentioned that the early stages of Macrocera are practically unknown, in spite of the fact that many of the species are quite common. According to Falk \& 
Chandler (2005) larvae of this genus have been reared from a range of situations including clumps of turf, rotting wood and cave walls and are considered predaceous.

The oldest rearing records exist for two common species: M. fasciata Meigen, 1804 from larvae feeding on fungus growing in a cellar (Enslin 1906) and M. stigma Curtis, 1837 from a decaying trunk of Carpinus betulus (Winnertz 1863). Further collections using emergence traps (Jakovlev et al. 1994, Irmler et al. 1996, Økland 1999, Ševčík \& Roháček 2008; Jakovlev, J., Penttinen, J., Polevoi, A., Salmela, J. \& StåhlsMäkelä, G., in prep.) has revealed M. anglica Edwards, 1925, M. angulata Meigen, 1818, M. aterrima Stackelberg, 1945, M. centralis Meigen, 1818, M. parva Lundström, 1914, M. pilosa Landrock, 1917, M. stigma Curtis, 1837 and M. stigmoides Edwards, 1925 from rotten wood, $M$. crassicornis Winnertz, 1863, M. stigma, M. vittata Meigen, 1830 - from soil and litter and M. $f a-$ scipennis Staeger, 1840 from tussocks of the grass Scirpus sylvaticus.

* Macrocera fasciata Meigen, 1804. 2 ઠิ઼, Site 3, reared from damp moist log of aspen bearing Datronia mollis, 27.VI.-24.VII.2006. Larval webs were under the loose bark on the underside of the log. Formerly it was reared from some fungus growing in a cellar (Enslin 1906) and from larvae found in hollows of an aspen tree (Plassmann 1971).

* Macrocera pilosa Landrock, 1917. 1 đ̊, Site 1, reared from rotten fallen trunk of Corylus avellana. Larval webs were on decaying sapwood covered with resupinate fruiting bodies of Antrodiella romellii, 16.V.-25.VI.2007. Formerly obtained in emergence traps over beech logs and spruce stumps (Økland 1999).

\subsubsection{Family Mycetophilidae}

Subfamily Mycomyiinae

Genus Mycomya Rondani

Among the 89 species of Mycomya recorded in Europe rearing records exist for about one-third of them. The larvae of this genus spin delicate slimy webs usually on the under surface of barkgrowing fungi, or on fungal mycelium under bark. There are, however, some species that could develop also in soil and litter, e.g. M. annulata (Meigen, 1818), M. britteni Kidd, 1955, M. levis Dziedzicki, 1885, M. marginata (Meigen, 1818) and M. shermani Garrett, 1924, that have been reared from soil and ground vegetation using emergence traps (Jakovlev et al. 1994, Økland 1999, Ševčík \& Roháček 2008) and M. nitida (Zetterstedt, 1852) found in burrows of rodents (Hackman 1963). Although larval habits of Mycomya are similar to those of Orfelia and Macrocera their larval diet is unknown. According to Laštovka (1972) Mycomya larvae are viewed as zoophagous, although the study of gut contents of $M$. marginata has verified their mycophagy (Parmenter 1953).

Known fungal hosts have been listed by Väisänen (1984) and Jakovlev (1994) but according to Falk \& Chandler (2005) accuracy the old rearing records, e.g. for $M$. griseovittata (Zetterstedt, 1852), M. ornata (Meigen, 1818) and $M$. punctata (Meigen, 1818) is doubtful. Additional fungal hosts have been reported by Chandler (1993a) and by this investigation. The list of known fungal hosts incorporates mostly bark-encrusting fungi, bracket polypores, and woodgrowing agarics but also some terrestrial fungi, e.g. Väisänen (1981) has reared M. circumdata (Staeger, 1840), M. permixta Väisänen, 1984, M. tenuis (Walker, 1856) and M. trilineata (Zetterstedt, 1838) from decaying fruiting bodies of Leccinum.

Mycomya (Mycomya) annulata (Meigen,

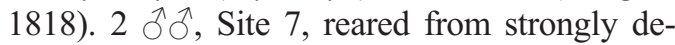
cayed pine trunks and branches retained in heaps lying on the ground after thinning in pine forest. Larvae in webs on the fungal mycelia, 24.V.14.VI.1994; 2 ふึ, Site 3, reared from decaying pine log partly bearing loose bark and covered with resupinate fungus Skeletocutis biguttulata, 14.IX.-14.XI.2007. Formerly reared from Polyporus sp. (Ostroverkhova 1979) and from Gyromitra gigas (Jakovlev 1995).

* Mycomya (Mycomya) bicolor (Dziedzicki, 1885). 1 ग, Site 21, ex. Gloeophyllum sepiarium on burned spruce stump, larvae in webs on the lower surface of fruiting bodies, 27.VII.-12.VIII. 2003. Formerly reported as "larvae on polypores" (Plassmann 1971, Sakharova 1977, Väisänen 1984) and "Fagus, under bark" (Plassmann 1971). 
Mycomya (Mycomya) cinerascens (Macquart, 1826). 1 ऽ, Site 17, ex. Trametes hirsuta on birch log, 13.VIII.-6.X.2002. Formerly reared from larvae found on fruiting bodies of Stereum (Edwards 1925, Chandler 1978), Thelephora terrestris (Jakovlev 1995) and Cortinarius sp. (Kurina 1994). Besides fruiting bodies the species has been collected with emergence traps over beech logs and stumps, alder and spruce stumps (Irmler et al. 1996).

** Mycomya (Mycomya) nitida (Zetterstedt, 1852). 1 Oे, Site 20, ex. Cylindrobasidium laeve on spruce stump under loose bark, larvae in webs, 29.V.-21.VI.2004. No former rearing records. Adults have been found in burrows of rodents (Hackman 1963).

** Mycomya (Mycomya) forestaria Plassmann, 1978. 1 J, Site 18, reared from decaying spruce stump in moist spruce-dominated forest along the river. Larvae in webs under bark, 25.V.4.VI.1996. No former rearing records.

Mycomya (Mycomya) marginata (Meigen, 1818). 1 ㄱ, 2 우오, Site 5, ex Sparassis crispa, 24.IX.-24.X.2008. Formerly reared from various wood-growing fungi, mostly bracket polypores, corticoid and jelly fungi (cf. Jakovlev 1994), also from Pleurotus (Hutson et al. 1980), Naucoria (Chandler (1993a), Simocybe (Alexander 2002) and from fungoid wood (Zaitzev 1994). Collected by emergence traps over dead wood (Irmler et al. 1996) and on tussocks of the grass Calamogrostis epigejos (Ševčík \& Roháček 2008).

Mycomya (Mycomya) occultans (Winnertz,

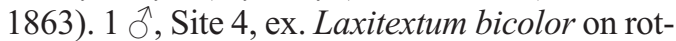
ting birch log, 18.VIII.-5.IX.2003. Formerly reared from bracket fungi growing on broadleaved trees, viz: Daedalea, Piptoporus (Winnertz 1863, Landrock 1927), Lenzites betulina, Plicaturopsis crispa (Eisfelder 1955), Inonotus radiatus (Väisänen 1984, record with question mark) and obtained with emergence traps over beech limbs (Schiegg 1999).

** Mycomya (Mycomya) ruficollis (Zetter-

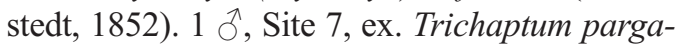
menum on fallen birch trunk, larvae in webs on the lower surface of fruiting bodies, 19.V.14.VI.2000. No former rearing records.

Mycomya (Mycomyopsis) trilineata (Zetter- stedt, 1838). 1 , Site 4, ex Laxitextum bicolor on rotting birch log, larvae in webs on the surface of fruiting bodies, 14.-30.VIII.2003; 1 ふै, Site 5, ex. Phlebia tremellosa on birch trunk bearing loose bark, larvae in webs on fruiting body, 27.VII.4.IX.2005. Formerly reared from rotting Leccinum scabrum (Väisänen 1984).

Mycomya (Mycomya) wankowiczii (Dzied-

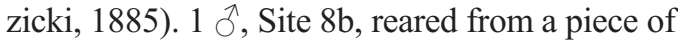
decaying silver birch log, 27.VII.-2.VIII.2005 (G.Várkonyi et al. leg.). Formerly reared from Stereum on fallen birch branches (Edwards 1925), Phallus impudicus (Plassmann 1971, Hutson et al. 1980) and Hypholoma lateritium (Eisfelder 1955).

Genus Neoempheria Osten Sacken

Larvae are web spinners on fungi or rotting wood (Falk \& Chandler 2005). Fungal hosts are recorded for two of eight European species; $N$. proxima (Winnertz, 1863) which has been reared from Bjerkandera adusta (Eisfelder 1955) and $N$. striata (see below).

** Neoempheria pictipennis (Haliday, 1833). $1 \hat{\jmath}, 1$, Site 1 , reared from larvae in webs on moist damp wood of fallen trunk of Corylus avellana, 23.VII.2007-8.VIII.2007. No former rearing records.

Neoempheria striata (Meigen, 1818). 3 $\widehat{\partial}, 2$ 오, Site 4, ex. Laxitextum bicolor on fallen birch trunk, 18.VIII.-2.IX.2003; 2 ふึ̄̄, Site 10, ex. Trichaptum pargamenun on birch stump, 14.29.VII.2003; 1 ऽ, Site 16, reared from larvae on the surface of fruiting bodies of Trametes hirsuta on birch stump, 30.VI.-24.VII.2009. Formerly was reared from larvae on fruiting bodies of wood-growing fungi: Trametes suaveolens (Dufour 1842), T. versicolor (Zaitzev 1994), Auricularia auricula-judae (Falcoz 1923), Thelephora terrestris (Jakovlev 1995). Khalidov (1984) published a rearing record of this species from Tapinella atrotomentosa which is very rarely infested with insect larvae. Matile (1963) found larvae of $N$. striata in webs on pine branches lying on the ground and considered them to be carnivorous on nematodes which became immobilised (probably with oxalic acid) on contact with the web. 


\section{Subfamily Gnoristinae}

\section{Genus Apolephthisa Grzegorzek}

This genus includes only one known species, $A$. subincana, which lives as larvae in mucilaginous tubes on the bark of deciduous trees encrusting with fungi (Madwar 1937).

Apolephthisa subincana (Curtis, 1837). 1 ते, Site 5, reared from larvae in webs under loose bark on soft decaying birch log (white rot) bearing resupinate fungus Hyphodontia barba-jovis, 24.VIII.-19.IX.2008; 1 , , Site 8b, reared from a piece of decaying aspen log, 31.VIII.-6.IX.2005 (G.Várkonyi et al. leg.). Formerly reared from Hyphodontia paradoxa (Edwards 1925) and Phlebia radiata (Trifourkis 1977).

\section{Genus Boletina Staeger}

This big genus comprises about 90 members in the Palaearctic and more than 70 species in Europe (Chandler 2004, 2009, Jakovlev \& Penttinen 2007). Rearing records exist only for seven of them viz: B. basalis (Meigen, 1818), B. dubia (Meigen, 1804), B. gripha Dziedzicki, 1885, $B$. nigricans Dziedzicki, 1885, B. nigricoxa Staeger, 1840, B. trivittata (Meigen, 1818) and B. trispinosa Edwards, 1913. Of these the commonest four species - B. basalis, B. gripha, B. nigricans and $B$. trivittata were obtained in emergence traps in a range of situations including rotting wood and soil litter (Jakovlev et al. 1994, Irmler et al. 1996, Økland 1999). Rotting wood is indicated as larval microhabitat for $B$. trispinosa by Schiegg (1999) and soil litter for B. nigricoxa by Plassmann (1971). The species of closely related genera, Saigusaia flaviventris (Staeger, 1840) and Aglaomyia ingrica (Stackelberg, 1948) develop in rotten wood as well (Chandler 1978, Zaitzev 1994).

There are two cases of rearing records of $\mathrm{Bo}$ letina from other substrates. B. gripha has been reared from fruiting bodies of Suillus bovinus by Kurina (1998) and B. dubia has been reared from liverworts by Cheetham (1920). Edwards (1925), based on the latter record and his own observations that the adults of many of the larger Boletina species are most frequently found along banks of mountain streams, supposed that they might develop amongst bryophytes and it seemed quite likely that they are liverwort feeders. Falk \& Chandler (2005) mentioned that Boletina and related genera develop in or on fungi, decaying wood or bryophytes. I have, however, never succeeded in finding Boletina larvae in liverworts or other bryophytes and also failed to rear any Boletina species from fungal fruiting bodies.

** Boletina edwardsi Chandler, 1992. 1 ô, Site 3 , reared from decaying pine log, partly bearing loose bark and fruiting bodies of polypores. The larvae were found within soft damp rotten wood bearing the resupinate fungus Skeletocutis biguttulata, 22.V.-14.VII.2007. No former rearing records.

Boletina gripha Dziedzicki, 1885. 4 ふ઼ે, Site 18 , reared from damp decaying wood (brown rot)

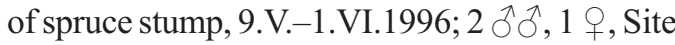
5 , reared from huge spruce log bearing loose bark; larvae on the surface of decaying wood (white rot) covered with Resinicium bicolor, 28.V.-21.VI.2008. Formerly reared from decaying wood of pine where larvae live in large colonies (Jakovlev et al. 1994), spruce (Jakovlev 1995), from soil in pine forest (Jakovlev et al. 1994) and from fruiting bodies of Suillus bovinus Kurina (1998).

* Boletina nigricans Dziedzicki, 1885. 1 ô, Site 3, reared from fallen birch trunk, larvae in white sapwood under bark bearing Hyphodontia barba-jovis, 22.IV.-11.VI.2006. Formerly was obtained in emergence traps on soil, the ground vegetation, moss carpets (Jakovlev et al. 1994, Økland 1999) and over rotten wood (Jakovlev, J., Penttinen, J., Polevoi, A., Salmela, J. \& StåhlsMäkelä, G., in prep.).

Boletina nigricoxa Staeger, 1840. 1 ภ, Site 11, reared from larvae found in thick litter of fallen leaves of Alnus glutinosa woodland. Larvae collected on 27.IX.2007 overwintered; adults emerged next spring, 25.IV.2008. Plassmann (1971) cited the old record of Beling (1875) who found larvae of this species between decayed leaves in soil litter in deciduous forest. My finding suggests a possible association of larvae with rotting plant material.

** Boletina populina Polevoi 1995. 1 ふ઼, Site 3 , reared from larvae collected in rotten wood of damp spruce log covered with Antrodia serialis, 22.V.-14.VI.2007. No former rearing records. 
Genus Ectrepesthoneura Enderlein

Larvae of this genus, which includes ten species in Europe, are generally known to develop on rotten wood bearing fungal growth. Two species, $E$. colyeri Chandler, 1980 and E. hirta (Winnertz 1863) were repeatedly hatched from decaying wood, chiefly ash and oak, but rearing records with named fungal hosts exist only for the commonest species E. hirta (Chandler 1978).

* Ectrepesthoneura colyeri Chandler, 1980. 1 స. Site 5, reared from decaying spruce log lying on moist swampy soil partly covered with moss. The larvae were found within soft whitish rotten wood under loose bark bearing several small fruiting bodies of Skeletocutis amorpha, 24.VII.21.VIII.2008. Formerly collected with emergence traps over rotten logs of ash and oak (Økland 1999, Martinsen \& Søli 2000).

Ectrepesthoneura hirta (Winnertz 1863). 1 ภ, Site 5, reared from larvae collected in decaying spruce $\log$ on whitish sterile fungal tissue (? Resinicium bicolor) encrusting inner layer of

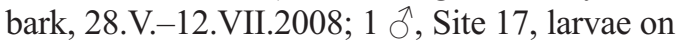
very rotting, barkless, thin pine log covered with Skeletocutis biguttulata, 21.VIII.-22.IX.2008. Formerly reared from Trametes versicolor (Winnertz 1863), from rotten pine wood (Matile 1964) and obtained in emergence traps over rotten logs of ash, oak and pine (Økland 1999, Martinsen \& Søli 2000).

\section{Genus Tetragoneura Winnertz}

This genus includes three species in Europe, of which rearing records exist only for T. sylvatica.

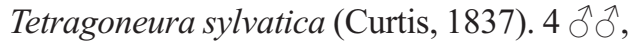
3 우, Site 1, reared from strongly decayed fallen trunk of hazel (Corylus avellana) bearing resupinate fruiting bodies of Hyphodontia paradoxa and $H$. radula, 27.VII.-4.IX.2006. The larvae in slime tubes on the edges of fruiting bodies where they are attached to bark and beneath loose bark. Formerly recorded as larvae in slight slimy web on mouldy branches (Edwards 1925) and on fruiting bodies of Hyphodontia paradoxa (Madwar 1937, Chandler 1978).

\section{Subfamily Sciophilinae}

\section{Genus Acnemia Winnertz}

Six species in Europe, all are believed to be asso- ciated with dead wood and lignicolous fungi (Falk \& Chandler 2005), but rearing records exist only for A. nitidicollis (Meigen, 1818). A record of $A$. amoena Winnertz, 1863 in the list of saproxylic insects in Britain (Alexander 2002) as a relict ancient woodland species that has been reared in Europe from Thelephora and Paxillus is in error and these details actually related to Neoempheria striata (Peter Chandler, pers. comm).

**Acnemia falcata Zaitzev, 1982a. 1 ふै, Site 21 , reared from larvae in webs beneath fruiting body of Rhodonia placenta growing on burned spruce stump, 24.VII.-28.VIII.2003. No former rearing records.

Acnemia nitidicollis (Meigen, 1818). 1 ô, Site 3, reared from larvae under the bark of decaying spruce log bearing resupinate fruiting bodies

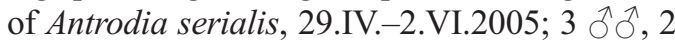
우, Site1, reared from strongly decaying fallen trunk of grey alder, larvae in webs under bark covered with moss and bearing fruiting bodies of Fomitopsis pinicola, 16.V.-18.VI.2007. This was formerly reared from fruiting bodies of Leccinum (Hackman \& Meinander 1979, Jakovlev 1995) from rotten wood (Edwards 1925, Landrock 1940) and collected with emergence traps over logs (Irmler et al. 1996, Økland 1999), soil (Irmler et al. 1996) and tussocks of the grass Calamagrostis epigejos (Ševčík \& Roháček 2008).

\section{Genus Leptomorphus Curtis}

Larvae of the three species distributed in Europe, L. forcipatus Landrock, 1918, L. subforcipatus Zaitzev \& Ševčík, 2002 and L. walkeri Curtis, 1831, are found in webs on bark-growing fungi (Chandler 1978, 1993a, Zaitzev \& Ševčík 2002). Two other species: L. panorpiformis Matsumura, 1916 and L. quadrimaculatus Matsumura, 1915, found only in the East Palaearctic, develop on the surface of decaying wood covered with fungal mycelium (Zaitzev 1994, Zaitzev \& Ševčík 2002).

Leptomorphus (Leptomorphus) forcipatus Landrock, 1918. 4 J, Site 7, ex Trichaptum abietinum on spruce log, 11.VI.-24.VII.2000; 2 ऽิग, 1 , Site 10, ex Trichaptum abietinum on spruce log, 4.VI.-17.VII.2008; 1 , Site 5, ex. Stereum subtomentosum on grey alder log, larvae 
in webs on fruiting bodies, 17.VIII.-2.IX.2003. My new records confirm formerly recorded fungus hosts from Trichaptum (Jakovlev 1995) and Stereum (Zaitzev \& Ševčík 2002). Økland (1999) has obtained this species in an emergence trap over a dead spruce log.

\section{Genus Phthinia Winnertz}

Eight species are currently known from Europe. Rearing records existing for one European species, P. humilis Winnertz, 1863 (Edwards 1925) and two species from East Palaearctic, $P$. lenae Zaitzev, 1984 and P. hyrcanica Zaitzev, 1984 (Zaitzev 1994) indicate that larvae develop in webs on the surface of fungal mycelium and moulds on rotten wood. $P$. humilis and $P$. winnertzi Mik, 1869 have been obtained in emergence traps on soil, moss carpets and ground vegetation (Økland 1999) and over decaying logs (Jakovlev, J., Penttinen, J., Polevoi, A., Salmela, J. \& Ståhls-Mäkelä, G., in prep.). For $P$. winnertzi unlike other Phthinia species there are rearing records from fruiting bodies of agarics (Kurina 1994, Alexander 2002).

** Phthinia congenita Plassmann, 1984. 1 ภ, Site 5, reared from strongly decayed, moss-covered spruce log lying on moist swampy ground, larvae in webs within cavities in softened, moist wood bearing thick resupinate Asterodon ferruginosus (both fertile and sterile tissues), 24.VI.-24.VII.2008. No former rearing records.

** Phthinia mira (Ostroverkhova, 1977). 4 $\widehat{\jmath} \widehat{\jmath}, 1$, , Site 5 , reared from decaying spruce log, cocoons and larvae in webs on whitish resupinate fungus Resinicium bicolor (both fertile and sterile tissues) encrusting inner layer of loosened bark, 29.V.-24.VI.2008. No former rearing records.

Phthinia winnertzi Mik, 1869. 1 J, Site 5, ex. Asterodon ferruginosus on spruce log (in company with Phthinia congenita), 24.VI.-24.VII. 2008. Formerly obtained in emergence traps over decaying log of Alnus glutinosa (Jakovlev et al. 2006) and reared from wood-growing Pholiota (Alexander 2002) and terrestrial Russula flava (Kurina 1994).

\section{Genus Polylepta Winnertz}

Three species in Europe (Chandler 2004), of these two common ones, $P$. guttiventris Zetterstedt, 1852 and $P$. borealis Lundström, 1912, have been obtained with emergence traps over dead wood (Jakovlev et al. 1994, Irmler et al. 1996) soil and ground vegetation (Økland 1999).

Polylepta borealis Lundström, 1912. 1 ठૈ, Site 3, reared from soft, moist, brownish wood of spruce log covered with moss and bearing Antrodia serialis, 19.V.-16.VI.2005. Formerly was obtained with emergence traps from decaying pine wood (Jakovlev et al. 1994) and reared from Gyromitra esculenta (Jakovlev 1995).

\section{Genus Sciophila Meigen}

Larvae develop in webs on the surface of fungal fruiting bodies, especially the tougher lignicolous species where they probably feed on fungal spores (Falk \& Chandler 2005). Rearing records exist for about 30 species, e.g. about half of the known European fauna of Sciophila. Most of them are associated with wood-growing polypores, but some species are able to develop in folds of the apothecia of Pezizales, e.g. S. karelica Zaitzev, 1982 and S. modesta Zaitzev, 1982, or on soft fruiting bodies of terrestrial agarics, most often on Hydnum repandum and Lactarius species. Two Sciophila species: S. hirta Meigen, 1818 and S. lutea Macquart, 1826 are generalists known to live on a wide range of fungal hosts including both soft terrestrial fungi and hard polypores. Larvae of $S$. baltica Zaitzev, 1982 and $S$. nonnisilva Hutson, 1979 have been found on fungal mycelium on the surface of rotten wood (Zaitzev 1994).

Sciophila buxtoni Freeman, 1956. 1 ふ, Site 4, ex. Phellinus tremulae on aspen log, larvae in

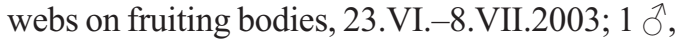
same place ex. Steccherinum nitidum on aspen twig, 23.VI.-8.VII.2003; 1 o, Site 6, ex. Steccherinum luteoalbum on decaying spruce log, 1.IX.-8.X.2003 (D. Schigel leg.); 1 ○े same place, ex Antrodiella pallescens growing on dead brackets of Fomes fomentarius on birch log, 1.IX.-8.X.2003 (D. Schigel leg.); 1 Ő, 2 우, Site 5, ex. Antrodiella pallescens growing on dead brackets of Fomes fomentarius on birch log, 4.IX.-3.XI.2008; 1 $\widehat{\jmath}$, Site 8c. Reared from a piece of decaying aspen log, 13.-19.VII.2005 (G.Várkonyi et al. leg.). This species has been formerly reared from a wide range of polypores: Daedaleopsis, Fomes, Fomitopsis, Laetiporus and Trametes. 
** Sciophila fenestella Curtis, 1837.1 ô, Site 21, ex. Rhodonia placenta on burned spruce stump, 24.VII.-16.VIII.2003. No former rearing records.

Sciophila hirta Meigen, 1818. $1 \precsim, 2$ 우, Site 12, ex Rigidoporus populinus on maple tree (Acer platanoides), 17.VIII.-2.IX.2003; 1 , , Site 21, ex. Rhodonia placenta on burned spruce log, larvae in webs on the surface of the resupinate fruit-

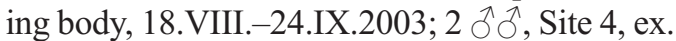
Phlebia gigantea on spruce log, 18.VIII.-2.IX. 2003; 1 J, 1 क, same place, ex. Pholiota squarrosa on standing dead birch, 10.IX.4.X.2003; 1ठ, Site2, ex. Bjerkandera adusta, young white sporophores on standing dead grey alder. 17.VII.-28.VIII.2005, 1 §, same place, ex Inonotus radiatus on standing dead grey alder, 17.VIII.-2.IX.2005; 1 o,1 $q$, Site 15, ex. Polyporus melanopus on the ground along roots of dead birch, 2.IX.-13.10.2008; 1 §, 3 우, Site 5, ex Sparassis crispa on roots of dead pine, 24.IX.-2.XI.2008. Formerly reared from a range of polypores and epigeic soft fungi.

** Sciophila jakutica Blagoderov, 1992. 1 ô, Site 21, ex. Rhodonia placenta on burned spruce stump, 18.VIII.-24.IX.2003 (in company with $S$. hirta). No former rearing records.

Sciophila lutea (Macquart, 1826. 1 ㄱ, 2 우, Site 1, ex. Verpa bohemica, 16.V.-25.VI.2007; 1

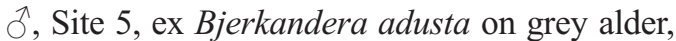
18.VIII.-24.IX.2008; 1 §, 4 우, same place, ex Lentinellus vulpinus on fallen birch trunk, 24.IX.-24.X.2008. Formerly reared from fruiting bodies of a wide range of fungi, including lignicolous and terrestrial species.

Sciophila pseudoflexuosa Kurina, 1991. 1 ô, Site 15, ex. Polyporus melanopus growing on the ground along roots of dead birch, 24.IX.27.X.2008. Formerly reared from Gyrodon lividus, Russula sp. (Rimšaite 2000), Albatrellus ovinus (Ševč́k 2006) and Lactarius species: $L$. helvus (Kurina 1991), L. necator (Rimšaite 2000), L. acerrimus, L. vellereus (Ševčík 2006) and L. deliciosus (Jakovlev et al. 2006). The closely related species Sciophila flexuosa Zaitzev, 1982 has been reared from Pleurotus citrinopileatus.

** Sciophila setosa Garrett, 1925. 1 ภ, Site 21, ex. Stereum subtomentosum growing on burned grey alder log, larvae in webs between sporophores, 31.V.-29.VI.2003. No former rearing records.

Sciophila varia (Winnertz, 1863) 1 ふै, Site 16, ex. Hydnum repandum, 23.VIII.-12.IX.2003. Formerly reared from Daedalea quercina, Leccinum scabrum (Landrock 1940), Cantharellus cibarius (Zaitzev 1982b), Hydnum repandum (Landrock 1940, Kurina 1994, Chandler 1987), Suillus bovinus, Paxillus involutus (Hackman \& Meinander 1979, Khalidov 1984).

\section{Genus Syntemna Winnertz}

Eleven species in Europe. According to a few rearing records existing only for $S$. hungarica Lundström, 1912 (Hutson et al. 1980) and $S$. nitidula Edwards, 1925 (Irmler et al. 1996) larvae develop in rotting beech wood on which they construct webs. No named fungal hosts are known.

** Syntemna daisetsuzana Okada, 1938. 1 ภ, Site 3, ex. Tomentella crinalis growing on the bark on the underside of decayed aspen log, 22.V.-22.VI.2006. No former rearing records. ** Syntemna penicilla Hutson, 1979. 2 ठิ ふૈ, Site $8 b$, reared from a piece of decaying pine log, 4.-14.VIII.2004 (G.Várkonyi et al. leg.). No former rearing records.

** Syntemna stylatoides Zaitzev, 1994. 2 ○う, 1 , , Site 3, reared from damp moist fallen aspen trunk, larval webs under the loose bark on the underside of the log covered with Datronia mollis, 22.V.-27.VI.2006. No former rearing records.

Subfamily Leiinae

\section{Genus Leia Meigen}

Nineteen species in Europe; rearing records exist for eight of them. Generally the larvae live in a slimy web on the under surface of fungi, or on the surface or under bark of rotting wood. $L$. cylindrica Winnertz, 1863 and L. picta Meigen, 1818 were obtained with emergence traps over decaying logs (Jakovlev, J., Penttinen, J., Polevoi, A., Salmela, J. \& Ståhls-Mäkelä, G., in prep.), L. bilineata Winnertz, 1863 is chiefly associated with wood growing polypores (Eisfelder 1955, Dely-Draskovits 1974), L. winthemii Lehmann, 1822 and L. bimaculata Meigen, 1808 - with terrestrial agarics (Jakovlev 1994, Chandler 1993a, Ševčík 2006). L. crucigera 
Zetterstedt, 1838 was reared from wood-growing Neolentinus tigrinus (Ševčík 2006). Some species show a tendency to saprophagous feeding, e.g. L. bilineata Winnertz, 1863 and L. piffardi Edwards, 1925 have been reared from the nests of birds and mammals (Hutson et al. 1980), L. arsona Hutson, 1978 - from various rotting plant material (Chandler \& Pijnakker, 2009) and obtained in emergence traps on tussocks of Glyceria maxima (Ševčík \& Roháček 2008).

Leia bilineata Winnertz, 1863. 1 ô, 1 9, Site 5. Reared from larvae in fine webs on underside of damp strongly decaying wood of spruce log, partly moss-covered, fungal mycelium within the wood, no fruiting bodies outside, 24.VIII.1.XI.2008. Formerly reared from Piptoporus betulinus, Phellinus igniarius (Kurina 1994), Phellinus sp (Rimšaite 2000), also from larvae found under the bark of oak, and in nests of the squirrel Sciurus vulgaris (Hutson et al. 1980), obtained in emergence traps over decaying ash and beech logs (Økland 1999).

** Leia picta Meigen, 1818. 1 ふૈ, Site 1, reared from rotten trunk of Tilia cordata lying on the ground. Larval webs were on the fungal mycelia under loose bark, 16.V.-25.VI.2008.

Leia winthemii Lehmann, 1822. 1 ऽ, Site 8a, reared from a piece of decaying pine log, 31.VIII.-6.IX.2004, G.Várkonyi et al. leg. 1 §, 4 우, Site 5, ex Lentinellus vulpinus on fallen birch trunk, larvae in webs on the under surface of sporophores, 24.IX.-24.X. 2008. Formerly reared from various fungi like Pleurotus, Paxillus, Lactarius and Peziza (Jakovlev 1994).

Subfamily Mycetophilinae

Tribe Mycetophilini

\section{Genus Dynatosoma Winnertz}

Thirteen species in Europe, all known larval microhabitats are bracket fungi, larvae live inside fruiting bodies. Rearing records exist for most of European species except the rarest ones, $D$. abdominale Staeger, 1840, D. majus Landrock, 1912, D. nobile Loew, 1873 and two recently described species, D. dichaeta Polevoi, 1995 and $D$. silesiacum Ševčík, 2001.

Dynatosoma fuscicorne (Meigen, 1818). 3 $\widehat{\partial} \hat{o}$, Site 5, ex Fomitopsis pinicola on pine,
24.VII.-6.VIII.2008; 3 ふぇં; 4 우, Site 12, ex Fomitopsis pinicola on grey alder, 19.VI.7.VII.2004 and 25.V.-16.VI.2007;1 §, Site 5, ex Postia caesia on spruce log, 24.VII.-5.IX.2008; $1 \hat{\jmath}$, same place, ex Climacocystis borealis on spruce $\log$, 24.IX.-7.X.2008; 1 ऽ, Site 20, ex. Trametes hirsuta on birch stump, 29.VII.18.VIII.2005. Formerly reared from a wide range of polypores (Chandler 1993a, Jakovlev 1994, Ševčík 2006).

* Dynatosoma reciprocum (Walker, 1848). 3 oิ $\hat{0}, 1$ 옹, Site 5, ex Resinicium bicolor on the surface of decaying sapwood (white rot) on the underside of the huge spruce trunk bearing loose bark, 28.V.-24.VII.2008; 2 o, Site 3, reared from larvae under bark of spruce log bearing Trichaptum abietinum, 12.VI.-24.VII.2008. Formerly reared from larvae on fungal mycelium in decaying wood (Zaitzev 1984c).

Dynatosoma thoracicum Zetterstedt, 1838. 2 $\hat{\jmath} \bar{o}$, Site 5, ex Postia caesia on spruce log, 18.VIII.-22.IX.2008. Formerly reared from Postia caesia only (Jakovlev 1994, Ševčík 2006). This species was identified according figures given in Zaitzev (2003, figs 56-1, 57-1, 57-2) which do not agree with the Zetterstedt's type material for $D$. thoracicum but belong to another, most likely undescribed species (Kjaerandsen et al. 2007).

\section{Genus Epicypta Winnertz}

Seven species in Europe, preimaginal stages are described only for E. aterrima (Zetterstedt, 1938) as the case bearing larvae develop in damp rotten wood (Brocher 1931, Steenberg 1938, Chandler 1981). According to Zaitzev (2003) E. scatophora (Perris, 1849) has similar larval habits.

** Epicypta fumigata (Dziedzicki, 1923). 1 $\checkmark$, Site 1, ex Hyphodontia paradoxa/radula on underside of a strongly decayed log of Corylus avellana, 24.V.-27.VI.2006. No former rearing records.

\section{Genus Mycetophila (Meigen)}

This is the biggest genus of fungus gnats with 131 species occurring in Europe. Edwards (1925, p. 631) wrote that the larvae of Mycetophila "live in the interior of fungi, some species attacking many different kinds, others being restricted to a single 
fungus-host. They may be found either in terrestrial or lignicolous fungi, though the same species will usually occur only in one of these classes of host". This has been confirmed by further studies; at present rearing records from fruiting bodies of identified fungi exist for ca 60 Mycetophila species, of these about half were reared chiefly from soft terrestrial agarics, another half - from woodgrowing fungi. The number of species of Mycetophila associated with dead wood and wood-encrusting fungi could be certainly increased during further studies. This study has added five species, and another five species, $M$. caudata Staeger, 1840, M. lapponica Lundström, 1906, M. nigrofusca Dziedzicki, 1884, M. stolida Walker, 1856 and M. sumavica Laštovka, 1963, for which fungal hosts were so far unknown have been obtained with emergence traps over dead wood (Jakovlev, J., Penttinen, J., Polevoi, A., Salmela, J. \& Ståhls-Mäkelä, G., in prep.).

Generally, Mycetophila species, particularly those associated with lignicolous fungi, tend to colonize a few related fungal hosts, e.g. M. adumbrata and $M$. vittipes Zetterstedt, 1852 - slime moulds; M. laeta Walker, 1848, M. tridentata Lundström, 1913 and M. trinotata Staeger, 1840 - polypores; M. attonsa Laffoon, 1957 - Fomitopsis pinicola; $M$. cingulum Meigen, $1830-P o-$ lyporus squamosus and Grifola frondosa; M. forcipata Lundström, 1911 - Piptoporus betulinus. There are, however several generalists like $M$. alea Laffoon, 1965, M. fungorum De Geer, 1776, M. ichneumonea Say, 1823, M. luctuosa Meigen, 1830, M. marginata Winnertz, 1863, M. ocellus Walker, 1848 able to colonize tens of fungal species from different orders and ecological groups.

** Mycetophila abiecta (Laštovka, 1963). 2 $\widehat{\jmath} \widehat{\jmath}$, Site 1, reared from moist fallen, moss-covered trunk of willow (Salix caprea) without fungal fruiting bodies, 4.-31.VIII.2007. No former rearing records.

Mycetophila adumbrata Mik, 1884. 1 ऽ, Site 20, ex Lycogala epidendrum on burned birch stump 27.VII.-24.VIII. 2008. Formerly reared from slime moulds (Zaitzev 2003, Ševčík 2006).

Mycetophila attonsa (Laffoon, 1957). 2 ฮิ ふે, Site 20, ex. Fomitopsis pinicola on burned pine stump, 19.V.-9.VI. 2003; 1 ふै, Site2, ex Fomitopsis pinicola on grey alder, 12.-28.VIII. 2005. Formerly reared only from Fomitopsis pinicola (Ševčík 2006).

Mycetophila autumnalis Lundström, 1909. 1 $\lambda$, Site 5, reared from larvae under loose bark of spruce log on thick sterile fungal tissue on the surface of decayed wood, 29.V.-4.VII.2008. Formerly reared from larvae found on fungal mycelium under bark of rotting spruce log (Zaitzev 2003).

Mycetophila bialorussica Dziedzicki, 1884. 3 $\hat{\jmath} \overline{0}$, Site 15, ex. Polyporus melanopus on the ground along roots of dead birch, 2.IX.13.X.2008. Probably confined to Polyporus as confirmed by recent observations (Zaitzev 2003, Ševčík 2006).

**Mycetophila bohemica (Laštovka, 1963). 1 $\lambda$, Site 5 , reared from thin top piece of strongly decayed spruce log bearing resupinate fruiting bodies of Leucogyrophana romellii, larvae under bark, 29.V.-4.VII.2008. No former rearing records.

** Mycetophila dziedzickii Chandler, 1977. 1

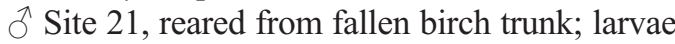
under loose bark bearing fruiting bodies of Scytinostroma galactinum, 19.V.-19.VI.2003. No former rearing records. The related species $M$. lunata Meigen, 1804 has been reared from Coniophora puteana (Chandler 1993a) and Hygrophoropsis aurantiaca (Kurina 1994).

Mycetophila flava Winnertz, 1863. 1 ऽ, Site 21, ex Neolentinus lepideus on burned pine stump, 9.-28.VI.2003. Formerly reared from the same fungus species, also from Leccinum, Amanita, Kuehneromyces, Inocybe (Jakovlev 1994) and Pleurotus (Rimšaite 2000).

Mycetophila formosa Lundström, 1911. 2

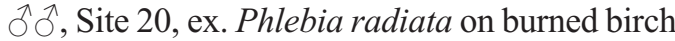
trunk, 6.VII.-13.VIII.2005; 1 Site 5, reared from moist, whitish, strongly decayed wood of spruce log bearing Trechispora hymenocystis, 16.VIII.- 11.IX.2008. Formerly reared from Phlebia radiata (Edwards 1925, Buxton 1960).

Mycetophila fungorum De Geer, 1776. 1 गे, 3 $\circ$, Site 5, ex. Armillaria mellea-group, 18.VIII.-6.IX.2003. Formerly reared from tens of species of agarics (Jakovlev 1994) and obtained with emergence traps over dead wood (Jakovlev et al. 1994), soil and ground vegetation (Økland 1999).

Mycetophila hetschkoi Landrock, 1912. 4 ๙ð ㄱ, 3 우, Site 7, ex. Bankera fuligineoalba, 7.- 
29.IX.1998. Formerly reared from Clavariadelphus, Ramaria, Bankera and Sarcodon (DelyDraskovits 1974, Jakovlev 1994) and probably confined to this fungal host group.

Mycetophila ichneumonea Say, 1823. 1 त, Site 5, ex. Armillaria mellea-group, 18.VIII.6.IX.2003. Formerly reared from various agarics.

Mycetophila laeta Walker, 1848. 1 ふै, Site 14, ex Fomitopsis pinicola on grey alder, 4.V.13.VI.2008. Formerly reared from the same fungus species (Zaitzev 1984c, Jakovlev 1995, Ševčík 2006), Phellinus igniarius (Kurina 1994), and $P h$. tremulae (Rimšaite 2000).

** Mycetophila lubomirskii Dziedzicki, 1884. 1 ${ }^{\lambda}$, Site 5, reared from larvae in rotting wood of spruce log with Steccherinum luteoalbum on the surface, 24.VII.-6.VIII.2007; 3 § Site 5, ex. Asterodon ferruginosus (both fertile and sterile tissues) on strongly decayed, moss-covered spruce log lying on moist swampy ground, 25.VIII.-19.IX.2008. No former rearing records.

Mycetophila luctuosa Meigen, 1830. 1 ð, Site 21, ex Neolentinus lepideus on burned pine stump, 9.-28.VI.2003 (in company with Mycetophila flava). Formerly reared from wood-growing Kretzchmaria deusta, Chondrostereum purpureum (Buxton 1960), Sebacina incrustans (Chandler 1993a), Neolentinus tigrinus and Pleurotus spp (Ševčík 2006), Trametes versicolor (Plassmann 1971) and a wide range of epigeic fungi, mostly Russulaceae.

Mycetophila marginata Winnertz, 1863. 2 ๙ิㄱ, 3 우, Site 4, ex Bjerkandera adusta on spruce stump, 2.-18.IX.2003; 4 $\precsim, 2$ 우, Site2, ex Bjerkandera adusta on grey alder, 12.VIII.-

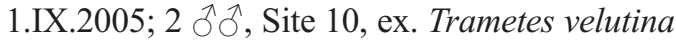
on birch stump in clear-cut, 31.VIII.-16.IX.2008. This species is polyphagous in wood-growing fungi, but was also reared from the epigeic Paxillus involutus (Madwar 1937), Hebeloma crustuliniforme and Russula vesca (Chandler 1993a).

Mycetophila ocellus Walker, 1848. 1 ô, Site 4, ex Bjerkandera adusta on spruce stump, 2.18.IX. 2003; $1 \hat{\jmath}$, same place, ex Phlebia radiata on decaying birch log, 24.V.-12.VI.2006; 1 , Site 4, ex Stereum rugosum on grey alder lying on the ground, 12.V.-29.V.2007. This species is polyphagous in many wood-growing fungi (Jakovlev 1994), but was also reared from terres- trial agarics like Chroogomphus, Amanita and Psathyrella (Chandler 1993a).

Mycetophila strigatoides Landrock, 1927. 1 $\lambda$, Site 15, ex. Polyporus melanopus, on roots of dead birch, 27.VIII.-29.IX.2008. Formerly reared from Trametes (Zaitzev 1984c), Polyporus, Neolentinus (Jakovlev 1995, Ševčík 2006), Lyophyllum (Rimšaite 2000) and Russula (Jakovlev 1995).

Mycetophila subsigillata Zaitzev, 1999. 1 ภ, Site 10, ex. Hohenbuehelia petaloides on decayed slash-residues on clear-cut, 23.VI.20.VII.2002. Formerly reared from Clitocybe sp. (Zaitzev 2003). This species has recently been segregated from the closely related $M$. sigillata Dziedzicki, 1884 and, therefore, records for $M$. sigillata cited in Jakovlev (1994) may apply to this species as well.

** Mycetophila xanthopyga Winnertz, 1863. $1 \hat{\delta}$, Site 20, ex. Phlebia radiata on birch trunk, 6.VII.-18.VIII.2005. No former rearing records.

Genus Phronia Winnertz.

At present 68 species are known from Europe, of these 62 species are found in the Nordic region (Jakovlev \& Polevoi 2009). Larval microhabitats are recorded only for twelve of them. Generally, Phronia larvae are protected with a kind of slime case and, therefore, able to live on the surface of wood encrusting fungi, on moulds growing on fallen wet branches, logging residues, etc. Since Phronia larvae are not common inhabitants of fungal fruiting bodies, fungal hosts have been recorded only for two species, $P$. siebeckii Dziedzicki, 1889 that has been reared from fruiting bodies of Calocera viscosa (Buxton 1960, Ševčík 2006) and P. braueri Dziedzicki, 1889 - from Pluteus salicinus (Chandler 1993a). P. braueri, and seven more Phronia species: P. basalis Winnertz, 1863, P. biarcuata Becker, 1908, P. caliginosa Dziedzicki, 1889, P. forcipula Winnertz, 1863, P. humeralis Winnertz, 1863, P. nitidiventris van der Wulp, 1859, P. strenua Winnertz, 1863 and $P$. tenuis Winnertz, 1863 have been reared from dead wood encrusting with fungi (Steenberg 1924, Edwards 1925, Buxton 1960) and obtained with emergence traps over decaying logs (Jakovlev et al. 1994, Irmler et al. 1996). P. taczanowskyi Dziedzicki, 1889 has been collected by emergence traps on tussocks of the grass 
Calamagrostis epigejos (Ševčík \& Roháček 2008).

Phronia humeralis Winnertz, 1863. 3 ๙ิ ๙ิ, 1 q, Site 10, ex. Chondrostereum purpureum on the fallen birch twigs retained in heaps in managed spruce forest, 29.V.-4.VII.2008. Formerly reared from Corticium (Buxton 1960).

Phronia siebeckii Dziedzicki, 1889. 2 ๙ેઝે, Site 9, ex. Tremella foliacea on fallen birch trunk, 18.VIII.-2.X.2005. Formerly reared from Calocera viscosa (Buxton 1960, Ševčík 2006).

Phronia strenua Winnertz, 1863. 3 ふふふ, Site 21 , reared from larvae on moulds on heavily decayed slash residues (fallen birch branches), 10.IX.-22.X.2003. Formerly has been reared from larvae bearing regular and fairly hard conical black cases, feeding on moulds on sodden fallen and barkless branches (Edwards 1925).

** Phronia unica Dziedzicki, 1889. 1 ơ, Site 3, ex. Physisporinus sanguinolentus on fallen spruce trunk, strongly decayed, wet and partly covered with moss, 11.VI.-24.VII.2007. No former rearing records.

Genus Trichonta Winnertz.

A big genus with 51 species in Europe, rearing records exist for 19 species, of these 18 are from bark-growing fungi. Larvae usually feed internally like those of Dynatosoma and Mycetophila, but some species have the larval habits similar to those of Phronia developing upon the surface of the fungus covered by a sheet of dry mucilage. According to Edwards (1925) T. foeda Loew, 1869 develops under patches of mucilage and excrement on the under surface of the fungus Stereum hirsutum; in most cases in association with $T$. falcata Lundström, 1911. Occurrence of larvae of T. hamata Mik, 1880 and T. perspicua van der Wulp, 1892 on fungal mycelium growing on rotting wood recorded by Zaitzev (2003) allows the suggestion that they are feeding on fungal mycelium, but may also indicate the pupation place. One species, $T$. venosa (Staeger, 1840) has been reared by Edwards (1925) from larvae living in puff-balls, Lycoperdon sp., thus differing markedly in habits from those of the other species members of Trichonta.

Trichonta brevicauda Lundstrom, 1909. 4

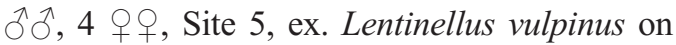
birch log, 24.IX.-7.X.2008. According to Gagné
(1981) in Vermont, (USA) was reared from the same fungal species.

Trichonta flavicauda Lundström, 1914. 1 ō, Site 5, ex. Trichaptum abietinum on spruce log, 29.V.-14.VI.2008. Formerly reared from Trichaptum laricinum (Zaitzev 2003).

* Trichonta hamata Mik, 1880. 1 đ̃, Site 13, ex. Peniophora laurentii on strongly decaying birch log lying on the ground, 24.IX.-13.X.2007. Formerly reared from fungal mycelium on the surface of rotting wood (Zaitzev 1984c).

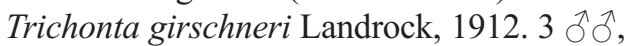
2 우, Site 3, ex. Datronia mollis on decaying aspen $\log$ hanging $0,5 \mathrm{~m}$ above the ground, 22.V.17.VI.2006. Formerly reared from a resupinate polypore on spruce in Central Russia (Zaitzev 1984c) and from Oxyporus sp. on Maackia amurensis in Russian Far East (Zaitzev 2003).

* Trichonta subfusca Lundström, 1909. 1 ふ, Site 19, ex. Exidia repanda on decaying trunk of mountain birch (Betula nana) lying on the ground, 20.VI.-9.VII.2006. Formerly reared from larvae on fungal mycelium in rotten wood (Zaitzev 1984c).

*Trichonta subterminalis Zaitzev \& Menzel, 1996. 1 đ, Site 4, ex. Laxitextum bicolor on aspen log, 18.VIII.-4.IX.2003. Rearing records from the encrusting fungus Peniophora incarnata (Chandler 1993a) exist for closely related species T. terminalis Walker, 1856.

Trichonta vitta (Meigen, 1830). 2 ふ઼ે, Site 1, ex. Hyphodontia paradoxa on decaying hazel log (Corylus avellana), 12.V.-25.VI.2006; 1 ふ, Site 12, ex. Gloeoporus dichrous on decaying elm log, 17.VIII.-14.IX.2008. Formerly reared from Hyphodontia paradoxa (Edwards 1925, Chandler 1993a).

Genus Zygomyia Winnertz.

Nothing is known on the life-history of this genus with thirteen species occurring in Europe, as well as in closely related genus Sceptonia Winnertz in spite of the abundance of some species. Edwards (1925, p. 643) suspected that larvae may be saprophagous in their habits since "The reduction in size and general black colouring of the adults are very frequent accompaniments of the adoption of a saprophagous mode of life by the larvae in other groups of Diptera". Indeed, fungal hosts have not hitherto been reported for any members of these 
genera. However, six species of Zygomyia, viz.: Z. kiddi Chandler, 1991, Z. pseudohumeralis Caspers, 1980, Z. semifusca Meigen, 1818, Z. pictipennis (Staeger, 1840), Z. vara (Staeger, 1840) and Z. zaitzevi Chandler, 1991 have been obtained with emergence traps over dead wood (Jakovlev, J., Penttinen, J., Polevoi, A., Salmela, J. \& Ståhls-Mäkelä, G., in prep.) that together with new rearing records listed below prove associations with wood-growing fungi.

** Zygomyia pictipennis (Staeger, 1840). 1 ऽ, Site 20, ex. Cylindrobasidium laeve on spruce stump, 14.VI.-18.VII.2005. No former rearing records.

** Zygomyia vara (Staeger, 1840). 1 ภ, 2 우, , Site 12, reared from larvae under bark of decaying fallen branch of mountain ash (Sorbus aucuparia) bearing numerous fruiting bodies of Encoelia fascicularis 18.VIII.-17.IX.2004. No former rearing records.

** Zygomyia zaitzevi Chandler, 1991. 1 ग, Site 3, reared from fallen birch trunk, the larvae under loose bark bearing Phlebia tremellosa, 23.VII.-13.VIII.2008. No former rearing records.

Tribe Exechiini

Genus Allodia Winnertz

A big genus with more than 40 species currently recorded in Europe. The larvae of those species for which rearing records exist (22 European species and two species from the Russian Far East) are associated with fruiting bodies of macrofungi, mainly soft terrestrial acarics and boleti. There is also a group of species within subgenus Brachycampta, viz.: A.(B.) barbata Lundström, 1909, A.(B.) elevata Zaitzev, 1984, A.(B.) foliifera (Strobl, 1910), A.(B.) neglecta Edwards, 1925, A.(B.) silvatica Landrock, 1912, A.(B.) triangularis (Strobl, 1895) and A.(B.) westerholti Caspers, 1980 (Chandler 1993a, Jakovlev 1994, Zaitzev 2003, Ševčík 2006), which are chiefly or exclusively associated with terrestrial saprotrophic Ascomycota belonging to the order Pezizales.

Allodia (Allodia) lugens Wiedemann, 1817. 4 §ô, Site 3, ex Armillaria borealis 18.VIII.12.IX.2004 (in company with M. strobli). Formerly reared from many species of macrofungi, chiefly agarics.
Allodia (Allodia) zaitzevi Kurina, 1998. 1 ๙ , Site 18, ex. Pluteus cervinus, 2.-23.VIII.1991 (erroneously reported in Jakovlev (1993) as Allodia ornaticollis). This species has recently been segregated from $A$. ornaticollis Meigen, 1818 and some former rearing records for $A$. ornaticollis in Jakovlev (1994) may apply to this species. Twelve species of macrofungi, Boletus edulis, Suillus bovinus, Gomphiduis glutinosus, Amanita muscaria, A. citrina, A. porphyria, Tricholoma terreum, Russula vinosa, $R$. flava, R.fragilis, $R$. paludosa and $R$. velenovskyi reported by Kurina (1998). Ševčík (2006) reared it from Collybia butyracea, Conocybe aporos, Cortinarius cumatilis and Russula sp. and it has been reared in Britain from Russula ochroleuca by J. Webb (Peter Chandler pers. comm.).

Allodia (Brachycampta) foliifera (Strobl, 1910). 2 गे, Site 1, ex. Exidia cartilaginea on rotting birch lying on the ground, 1.VI.-

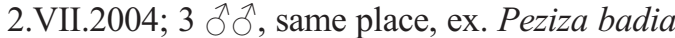
1.-27.VI.2004. Formerly reared from Peziza sp. (Jakovlev 1995, under the name of Allodia triangularis Strobl, 1895), Peziza repanda (Falk \& Chandler 2005) and Peziza micropus (Ševčík 2006).

Allodia (Brachycampta) neglecta Edwards, 1925. 1 Õ, Site 1, ex. Verpa bohemica, 20.V.12.VI.2004. Formerly reared from Pezizales of the genera Verpa, Gyromitra and also from the lignicolous agaric Kuehneromyces mutabilis (Jakovlev 1994).

Allodia (Brachycampta) silvatica Landrock, 1912. 2 ๙̋, Site 16, ex. Peziza succosa, 22.VII.14.VIII.2001; 1 ơ, Site 10, ex Peziza sp., 14.VI.7.VII.2008. This species has never been reared from fungal species other than Pezizales.

\section{Genus Anatella Winnertz}

The genus comprises twenty-nine species in $\mathrm{Eu}-$ rope, mostly of unknown biology. The larvae probably develop in such microhabitats that make them difficult to find. Reliable rearing records exist only for two species and suggest associations with small lignicolous ascomycetes and jelly fungi. A. flavomaculata Edwards, 1925 has been reared from Cydoniella acicularis (Chandler 1993a), the other species, Anatella lenis Dziedzicki, 1923 has been reared from Ascocoryne sarcoides (Ševčík 2006) and from Exidia glandulosa 
(Plassmann 1971). There are also records for $A$. flavomaculata and $A$. minuta Staeger, 1840 from agarics Amanita, Pholiota and Lactarius (Khalidov 1984) that need confirmation. A. ciliata Winnertz, 1863 was collected with emergence trap over dead wood (Jakovlev et al. in prep.). I have never succeeded in rearing Anatella from fungi with the exception of one female that is not possible to identify.

Anatella sp. 1 q, Site 5, ex. Asterodon ferruginosus (both fertile and sterile tissues) on strongly decayed, moss-covered spruce log lying on moist swampy ground, 25.VIII.-24.IX.2008.

Genus Brevicornu Marshall

The 38 species of this genus occurring in Europe do not resemble closely related species of Allodia as well as most other Exechiini in their habits. Associations with fungal hosts are recorded only from southern Europe and due to confused taxonomy of Brevicornu need confirmation in most cases. B. sericoma (Meigen, 1930) has been reared from Amanita (Falcoz 1926) and B. griseicolle (Staeger, 1840) - from several Cortinariaceae species: Hebeloma, Inocybe (Canzanelli 1941, Eisfelder 1955) and Cortinarius (Plassmann 1971). One unidentified Brevicornu female has been reared from Russula paludosa in Finland (Hackman \& Meinander 1979).

New records listed below as well as data obtained with emergence traps (Jakovlev, J., Penttinen, J., Polevoi, A., Salmela, J. \& StåhlsMäkelä, G., in prep.) for B. fennicum (Landrock, 1927), B. fuscipenne (Staeger, 1840), B. improvisum Zaitzev, 1992, B. ruficorne (Meigen, 1838 ), and $B$. sericoma (Meigen, 1830) show that at least part of the Brevicornu species develop in dead wood and in soil litter, feeding probably on microfungi.

Brevicornu sericoma (Meigen, 1830). 1 o, Site 20, ex. Chondrostereum purpureum on fallen birch trunk on burnt clear-cut, 31.VII.12.IX.2005. The old rearing record from Amanita rubescens (Falcoz 1926) needs confirmation.

** Brevicornu serenum (Meigen, 1830) 2 $\widehat{\partial} \widehat{A}$, Site 1, reared from rotting fallen trunk of willow (Salix caprea), larvae under bark covered with moss and bearing resupinate fruiting bodies of Phellinus conchatus, 12. -29.V.2006. No former rearing records.

\section{Genus Cordyla Meigen}

Rearing records exist for eleven of the fifteen species of European fauna, all from fruiting bodies of soft macrofungi; chiefly but not exclusively relate to Russula and Lactarius (Jakovlev 1994). Almost all of them were also collected with emergence traps from decaying wood (Økland 1999; Jakovlev, J., Penttinen, J., Polevoi, A., Salmela, J. \& Ståhls-Mäkelä, G., in prep.).

Cordyla murina Winnertz, 1863. 1 ô, Site 5, ex. Asterodon ferruginosus (both fertile and sterile tissues) on strongly decayed, moss-covered spruce log, 25.VII.-24.VIII.2008. Formerly reared from various soft agarics (Jakovlev 1994) and Scleroderma verrucosum (Falcoz 1926).

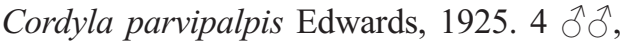
Site 7, reared from strongly decayed wood of pine log bearing Antrodia sp., 19.V.-24.VII.1998. Formerly reared from Russula (Sakharova 1977) and obtained in emergence traps over decaying pine twigs covered wood with fungal mycelium (Jakovlev et al. 1994).

\section{Genus Exechia Winnertz}

This genus incorporates 44 species in Europe; of these fungal hosts are known for 28 species. The larvae develop within soft fruiting bodies on various agarics, both terrestrial and wood growing, boletes and Russulales. Rearing records from other fungal hosts are known for a few species: $E$. cornuta Lundström, 1914 and E. lundstroemi Landrock, 1923 were reared from Neolentinus lepideus and from Hydnaceae, E. lucidula Zetterstedt, 1938, E. parva Lundström, 1909, E. separata Lundström, 1913 and E. spinuligera Lundström, 1913 - from Pezizales (Jakovlev 1994). Rearing records from bracket fungi exist only for Exechia fusca.

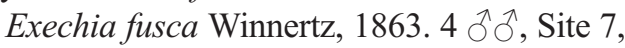
reared from strongly decayed wood of pine log bearing Antrodia sp., 19.V.-24.VII.1998 (in company with Cordyla parvipalpis); 3 ऽิ ภ, Site 5, ex. Armillaria mellea-group, 18.VIII.-6.IX. 2003. Formerly reared from tens of species of agarics (Jakovlev 1994), but there are also a few rearing records from bracket fungi: Trametes versicolor (Edwards 1925), T. gibbosa (Buxton 1960), soft polypores: Polyporus squamosus (Winnertz 1863) and records obtained with emergence traps over soil, litter (Irmler et al. 1996) and 
dead wood (Jakovlev, J., Penttinen, J., Polevoi, A., Salmela, J. \& Ståhls-Mäkelä, G., in prep.).

Genus Exechiopsis Tuomikoski

This big genus with more than 40 species in Europe was separated from Exechia by Tuomikoski (1966), based on morphological differences of the imago. The larval habits of these two genera are also not identical; Exechia incorporates species chiefly confined to soft fungi whereas the host range of the Exechiopsis is wider and include wood-encrusting fungi, at least for a few species.

Soft agarics are recorded as fungal hosts for seven Exechiopsis species of the European fauna. E. indecisa (Walker, 1856), E. clypeata (Lundström, 1911), E. intersecta (Meigen, 1918), E. fimbriata (Lundström, 1909), E. subulata (Winnertz, 1863), were reared from boletes and Tricholomataceae (Jakovlev 1994, Ševčík 2006), E. januarii (Lundström, 1913) - from Paxillus involutus (Khalidov 1984) and E. dumitrescae Burghele-Balacesco, 1972 - from unidentified wood-growing agarics (Zaitzev 2003). There are also rearing records obtained in Japan by Sasakawa \& Ishizaki (1999) for E. indecisa from Russula, for E. unguiculata (Lundström, 1909) from Mycena and for five Eastern species from agarics, chiefly wood-growing Mycenaceae.

Wood-growing fungi other than agarics could be the possible hosts for $E$. sagittata Laštovka \& Matile, 1974, E. pseudopulchella (Lundström, 1912), E. (Xenexechia) leptura (Meigen, 1830), which were obtained with emergence traps over dead wood (Jakovlev, J., Penttinen, J., Polevoi, A., Salmela, J. \& Ståhls-Mäkelä, G., in prep.) and for three species listed below.

Exechiopsis (Exechiopsis) subulata (Win-

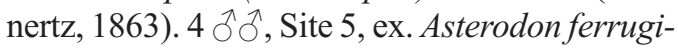
nosus (both fertile and sterile tissues) on strongly decayed, moss-covered spruce log lying on moist swampy ground 16.VIII.-11.IX.2008. Formerly reared from Suillus variegatus (Khalidov 1984). In Jakovlev (1994) this record was erroneously given as from Xerocomus subtomentosus.

Exechiopsis (Exechiopsis) clypeata (Lundström, 1911). 1 Site 5, ex. Asterodon ferruginosus (in company with E. subulata), 16.VIII.11.IX.2008. Formerly reared from Suillus bovinus (Khalidov 1984) and Mycena galericulata (Kurina 1998).
** Exechiopsis (Exechiopsis) pulchella (Winnertz, 1863). 1 ô, 1 , Site 3, ex. Scytinostroma galactinum, thick sterile tissue on the surface of decayed soft, fibrous and moist birch wood 31.VIII.-27.IX. 2006; 2 ठิ๋, 1 ㅇ, Site 5, ex. Asterodon ferruginosus, thick sterile tissue on moist, moss-covered decaying spruce log, 22.VIII.-24.IX.2008. No former rearing records.

Three very small genera: Pseudobrachypeza Tuomikoski, 1966, Pseudorymosia Tuomikoski, 1966 each comprises in Europe only one species and Stigmatomeria Tuomikoski, 1966 (two species), with hitherto poorly known larval microhabitats.

** Pseudobrachypeza helvetica (Walker, 1856). 1 S Site 5, reared from larvae on the wet layer of the inner side of bark covered with Resinicium bicolor (both fertile and sterile tissues), 15.VII.-22.VIII.2008. No former rearing records.

Pseudorymosia fovea (Dziedzicki, 1910). 3 $\widehat{\jmath} \widehat{\partial}$, Site 5, ex. Asterodon ferruginosus (in company with $E$. clypeata and E. subulata), 16.VIII.11.IX.2008. Formerly reared from a terrestrial agaric, Tricholoma fulvum (Eisfelder 1955).

Stigmatomeria crassicornis (Stannius, 1831).

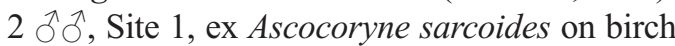
log, 16.V.-25.VI. 2008. Larvae in basal parts of conidia and apothecia growing in the crack of decaying wood. Formerly reared from truffles (Tuberaceae) (Edwards 1925, Chandler 1978, 2010).

\section{Discussion}

\subsection{Methodological conclusions}

The traditional rearing method by placing the sample with larvae into a rearing chamber has the value of providing exact information of the fungal hosts and has been successfully used by many researchers. However, although very effective for species developing internally in soft fruiting bodies, this method leads to high mortality of larvae living outside, in delicate webs on the hymenial surface on wood-growing polypores, which are more demanding to moisture conditions and need longer time for larval development that lasts, as a minimum, three to four weeks. 
Table. 2. Number and proportion of successful and unsuccessful cultures among different groups of fungi and samples without fruiting bodies. For polypores, corticeous fungi and dead wood: A operated in lab / B operated directly in the forest.

\begin{tabular}{|c|c|c|c|c|c|c|c|c|}
\hline No. of cultures $A / B$ : & $\begin{array}{l}\text { Soft } \\
\text { fungi }\end{array}$ & $\begin{array}{l}\text { Poly- } \\
\text { pores }\end{array}$ & $\begin{array}{l}\text { Corti- } \\
\text { coid } \\
\text { fungi }\end{array}$ & $\begin{array}{l}\text { Jelly } \\
\text { fungi }\end{array}$ & $\begin{array}{l}\text { Asco- } \\
\text { mycota }\end{array}$ & $\begin{array}{l}\text { Myxo- } \\
\text { mycota }\end{array}$ & $\begin{array}{l}\text { Dead } \\
\text { wood }\end{array}$ & Total \\
\hline Successful & 31 & $93 / 6$ & $34 / 6$ & 6 & 16 & 1 & $1 / 7$ & 201 \\
\hline Unsuccessful & - & $72 / 4$ & $66 / 4$ & 6 & 9 & 2 & $78 / 33$ & 242 \\
\hline Total cultures & 31 & 165 & 110 & 12 & 25 & 3 & 119 & 465 \\
\hline $\begin{array}{l}\text { Successful } \\
\text { cultures A/B (\%) } \\
\text { No. of fungal }\end{array}$ & 100 & $56.4 / 60$ & $30.9 / 60$ & 50.0 & 64.0 & 33.3 & $1.3 / 17.5$ & 43.2 \\
\hline species cultured & 12 & 33 & 19 & 5 & 7 & 1 & - & 77 \\
\hline $\begin{array}{l}\text { Of these successful } \\
\text { No. of fungus gnat }\end{array}$ & 12 & 31 & 16 & 4 & 6 & 1 & - & 71 \\
\hline species obtained & 17 & 60 & 51 & - & 7 & 2 & 5 & 110 \\
\hline
\end{tabular}

This could be a reason why most rearing records of fungus gnats relate to macrofungi with well pronounced fruiting bodies, soft at least when young. This does not give a true impression of the entire range of their fungal hosts and I, therefore, tried to sample other fungal groups, such us polypores with resupinate fruiting bodies, corticeous fungi and jelly fungi that have seldom or never been examined by entomologists.

As verified by my experience, both decaying wood and wood growing fungi are exploited by a range of fungus gnat species; they may be found within fruiting bodies or on their surface, on rotting sapwood and inner layer of loosened bark of fallen trunks, branches and well decayed stumps impregnated with fungal mycelia. Wet decaying heartwood is also a suitable place to find larvae of certain fungus gnat species. These breeding sites favourable to saproxylic fungus gnats are especially common in old-growth forest sites where fallen wood is left to decay on the ground but occur also in city forests and parks harbouring old deciduous trees with holes and moribund parts.

On the other hand, to find full-fed fungus gnat larvae and manage successful rearing of adults is a matter of luck. Larval webs could be easily found outwardly because of their glistening, but the procedure of detaching them together with resupinate fruiting bodies to place into a rearing chamber very often leads to the forthcoming death of the larvae. The reasons could be deterioration of the substrate, destruction of larval webs and altering microclimatic conditions, first of all moisture. Not least is the problem of food supply; larvae of many keroplatids and some mycetophilids, like Neoempheria, could be predatory feeding on the other wood-decay associates which they encounter, and simply die because of starvation.

A range of fungus gnat larvae including some Gnoristinae and Mycetophilinae live in softened wood without well-pronounced webs and in some species are aggregated in large colonies. Generally, they are easier to culture but only in those cases when the wood becomes soft enough to allow detaching carefully a piece containing larvae from the trunk or stump. Another option is to find larvae on relatively small pieces of wood, e.g. on fallen branches, that make them easier to transfer into rearing chambers.

In this study a wide range of wood-growing fungi with different characters of fruiting bodies were used for rearing fungus gnat larvae. The pooled sample comprises a total of 465 cultures, including both fruiting bodies and pieces of decaying wood with fungal mycelia (Table 2). Of these only $43.2 \%$, i.e. 193 cultures of 71 fungal species and eight cultures with fungal mycelia (altogether 201 cultures) were successful, i.e. reared imagoes occurred in the containers.

Comparing the percentages of successful and unsuccessful cultures that were transferred to the laboratory (A) and those operated directly in the forest (B), one with another, indicates for which group of fungi the methods of rearings implemented in this investigation are applicable and for 
which they are in need of further modification.

As expected, culturing soft and ephemeral fruiting bodies of wood-growing agarics like $\mathrm{Ar}$ millaria, Hypholoma, Pholiota, as well as Neolentinus, Lentinellus and some relatively soft polypores like Polyporus, Postia, Sparassis (totally 31 cultures), were always successful.

Difficulties occurred with species associated with bark-encrusting fungi and decaying wood on which my study was chiefly focused. Samples of polypores with fungus gnat larvae and cocoons have produced adult flies in $56.4 \%$ of cultures, those with corticeous fungi - in 30.9\%. Among Ascomycotina cultures with large fruiting bodies of saprotrophic Pezizales were usually successful while those with wood-growing species failed in most cases. Number of cultures of jelly fungi and slime moulds (that were successful in $50 \%$ and $33 \%$ respectively) were too small to make any conclusions based on this investigation. Finally, the lowest proportions of successful cultures were obtained using samples with larvae that develop in decaying wood without fruiting bodies. These fungus gnat species seem almost uncultivable under laboratory conditions and most of my rearing experiments failed.

This leads to a conclusion that the results obtained with the emergence traps for rearing species from pieces of dead wood or sections of entire logs in their original locality, thus keeping the substrate and microclimatic conditions almost unchanged, should form the basis of the rearing records. However, although very practical for revealing larval microhabitats, the majority of records refers only to a tree species and stage of decay and, therefore, is not valuable to specify the exact fungal host species.

Väisänen (1981) pioneered the rearing method surrounding the sporophore with an open metal cylinder to prevent pupating larvae from leaving, and then used the soil samples for rearing adults during the winter. The results obtaining four species of Mycomya that had never been reared from soft fungi before have indicated high effectiveness of this method that could be used for further rearing of larvae of the fungus gnat species that develop in soil and litter.

In this study focused on wood-growing fungi, Väisänen's method with soil samples is not applicable. However, as it was mentioned in the me- thods section, sixty containers (ten with polypores, ten with corticeous fungi and forty with larvae in/on decaying wood without fungal fruiting bodies) were operated directly in forest that allowed them to pupate in more natural conditions. Although these numbers are disproportionally small in comparison with ca 400 containers transferred into the laboratory, I have found that this method has some advantages in the case of fungoid wood samples, where the percentage of successful cultures was 17.5 versus $1.3 \%$ using standard breeding techniques. In case of fruiting bodies the effectiveness of both methods was about the same.

\subsection{Associations with different fungal hosts}

Current knowledge on the larval diet of fungus gnats is almost exclusively based on the fact that they are associated with fungi growing on different substrates and are, therefore, mycetophagous. Studies containing primary data that could verify mycophagy, predation or saprophagy as a type of larval nutrition are very scanty. Matile (1997) analysed all suitable literature based on the studies of the larval mouthparts (Madwar 1937, Plachter 1979b, Zaitzev 1979, 1984b), digestive system (Zaitzev 1983, 1984a), types and chemical contents of larval webs (Mansbridge 1934, Plachter 1979a) and proposed predation only for a few genera of Keroplatidae (e.g. Orfelia, Platyura, Xenoplatytura, Macrocera) and some Mycomyinae, e.g. Neoempheria, that live in webs on decaying wood or on soil litter. Other fungus gnat species associated with sporophores most probably feed on spores or/and hyphae, those living under bark and in rotting wood perhaps consumes hyphae only. There are also a few species found as larvae in nests of birds and mammals (some Docosia and Leia species), on the walls of caves (Speolepta leptogaster Winnertz, 1863) or amongst bryophytes (Gnoriste species - mosses, Boletina dubia - liverworts), that could be saprophagous or phytophagous, but this needs confirmation.

As regard to associations with different species of fungal hosts, fungus gnats as well as other Diptera associated with macrofungi are generally viewed as polyphagous and able to colonise fungi 
Table 3. Numbers and percentage of fungus gnat species with known and unknown larval microhabitats (Mhb) in Europe. Abbreviations of fungus gnat groups: Bol, Bolitophilidae; Dia, Diadocidiidae (including Sciarosoma); Dit, Ditomyiidae; Ker, Keroplatinae; Mac, Macrocerinae; Myc, Mycomyinae; Sci, Sciophilinae; Gno, Gnoristinae; Lei, Leiinae; Exe, Exechiini; Myce; Mycetophilini; Man, Manotinae.

\begin{tabular}{|c|c|c|c|c|c|c|c|c|c|c|c|c|c|}
\hline & \multirow[t]{2}{*}{ Bol } & \multirow[t]{2}{*}{ Dia } & \multirow[t]{2}{*}{ Dit } & \multicolumn{2}{|c|}{ Keroplatidae } & \multicolumn{7}{|c|}{ Mycetophilidae } & \multirow[t]{2}{*}{ Total } \\
\hline & & & & Ker & Mac & Myc & Sci & Gno & Lei & Exe & Myce & Man & \\
\hline Mhb known* & 21 & 4 & 4 & 17 & 10 & 33 & 52 & 25 & 14 & 113 & 123 & 1 & 417 \\
\hline$\%$ & 58.3 & 57.1 & 100 & 27.0 & 21.7 & 34.0 & 56.5 & 20.8 & 27.5 & 40.5 & 40.9 & 100 & 38.0 \\
\hline Mhb known** & 21 & 5 & 4 & 20 & 14 & 44 & 55 & 47 & 19 & 132 & 136 & 1 & 498 \\
\hline$\%$ ** & 58.3 & 71.4 & 100 & 31.7 & 30.4 & 45.4 & 59.8 & 39.2 & 37.3 & 47.8 & 45.2 & 100 & 45.4 \\
\hline Total in Europe & 36 & 7 & 4 & 63 & 46 & 97 & 92 & 120 & 51 & 279 & 301 & 1 & 1,097 \\
\hline
\end{tabular}

* Data obtained with emergence traps not included.

** Data obtained with emergence traps included.

belonging to different taxonomic and ecological groups. This is well confirmed by the existence of many generalist Diptera species which have been reared by various authors from tens species of mushrooms (Chandler 1978, Jakovlev 1994) and explained by the fact that soft and ephemeral fruiting bodies constitute an unpredictable food source (Hanski 1989).

Wood-growing fungi having relatively long lifespan of the fruiting bodies differ from epigeic fungi in that their occurrence is more predictable. This is consistent with many examples of monophagous species among fungivorous Coleoptera and allows one to assume that certain groups of these fungi might contain specialized species of Diptera as well (Jonsell \& Nordlander 2004). With regard to the species covered earlier, my records have confirmed host preferences to certain species of hard polypores (Keroplatus tipuloides, Mycetophila attonsa and M. laeta), soft polypores (Bolitophila aperta, Mycetophila bialorussica, Trichonta brevicauda and Dynatosoma thoracicum) and slime moulds (Mycetophila adumbrata). A more detailed study focused on tough lignicolous fungi may also throw light on the host preferences of the fungus gnat species that were reared for the first time during this investigation.

To estimate for how many fungus gnat species of the European fauna fungal hosts are actually known (i.e. reliable rearing records exist) at the moment of writing and how many species of fungi were ever recorded as fungal hosts, I tried to summarize all of the available rearing records of fungus gnats. For this I used data obtained both from this investigation and from the literature, including those cited in my summary (Jakovlev 1994, from where I have deleted doubtful records and species that have been further synonymised) and subsequent original rearing records (e.g. Chandler 1993a, Rimšaite 2000, Zaitzev 2003, Ševčík 2006).

The total numbers of fungus gnat species of the European fauna with known and unknown larval microhabitats and their percentage in different taxonomic groups of fungus gnats are presented in Table 3. Data obtained with traditional rearing methods (i.e. hand picking of the larvae with forthcoming rearing of adults in the rearing chambers) and the percentage of the species with known larval microhabitats within different families, subfamilies and tribes of fungus gnats are presented in the two first rows and marked with one asterisk. In the two following rows I calculated those values including data obtained with emergence traps (two asterisks).

A total of 417 species that comprises $38 \%$ of the European fungus gnat fauna have been at least once recorded as reared from larvae with indication of the fungal host or some microhabitat other than fungal fruiting bodies. If we add the records obtained with emergence traps, the total amount of the fungus gnat species with known larval microhabitats will equal 498. It means that the average percentage of the fungus gnat species with known larval microhabitats occuring in Europe is now $45.4 \%$, whereas for the remaining 599 species or $54.6 \%$, rearing records are absent so far. 
Table 4. Numbers of known fungal hosts from which rearing records of fungus gnats exist. Abbreviations of fungus gnat groups as in Table 3 .

Fungus gnat groups and no. of species reared from different fungal hosts

\begin{tabular}{|c|c|c|c|c|c|c|c|c|c|c|c|c|}
\hline \multirow{2}{*}{$\begin{array}{l}\text { Fungal group } \\
\text { (no. of fungal } \\
\text { host spp.) }\end{array}$} & \multirow[t]{2}{*}{ Bol } & \multirow[t]{2}{*}{ Dia } & \multirow[t]{2}{*}{ Dit } & \multicolumn{2}{|c|}{ Keroplatidae } & \multicolumn{6}{|c|}{ Mycetophilidae } & \multirow[t]{2}{*}{ Total } \\
\hline & & & & Ker & Mac & Myc & Sci & Gno & Lei & Exe & Myce & \\
\hline \multicolumn{13}{|l|}{ Agaricales: } \\
\hline Epigeic ( 240) & 17 & - & - & _- & - & 2 & 4 & 2 & 3 & 72 & 19 & 119 \\
\hline Wood-growing ( 60) & 15 & - & - & 1 & - & 2 & 6 & 1 & 5 & 51 & 23 & 104 \\
\hline Boletales $(\sim 70)$ & 10 & _- & - & 3 & - & 5 & 8 & 3 & 4 & 46 & 18 & 97 \\
\hline Russulaceae ( 90) & 3 & - & - & 1 & - & 1 & 7 & 1 & 5 & 44 & 21 & 83 \\
\hline \multicolumn{13}{|l|}{ Hydnums, ramarioid } \\
\hline \& clavarioid spp. $(\sim 20)$ & - & - & 1 & 1 & - & 5 & 9 & - & 3 & 11 & 4 & 34 \\
\hline Lycoperdales (5) & - & - & - & - & - & - & - & 1 & 1 & 6 & 1 & 9 \\
\hline \multicolumn{13}{|l|}{ Polypores: } \\
\hline Soft $(\sim 30)$ & 9 & - & 6 & 3 & - & 1 & 9 & 1 & 4 & 5 & 20 & 72 \\
\hline Hard $(\sim 60)$ & 1 & 1 & 5 & 10 & 2 & 14 & 23 & 6 & 7 & 4 & 36 & 121 \\
\hline Corticeous spp. ( 30) & - & 1 & 1 & 5 & - & 10 & 8 & 5 & 1 & 5 & 32 & 68 \\
\hline Jelly fungi $(\sim 10)$ & - & - & - & 2 & - & 3 & 3 & - & 2 & 7 & 8 & 25 \\
\hline Pezizales ( 20) & - & _- & - & 1 & - & 1 & 6 & 1 & 3 & 21 & 1 & 34 \\
\hline \multicolumn{13}{|l|}{ Wood-growing } \\
\hline Ascomycota $(\sim 10)$ & - & - & 1 & 1 & - & - & 3 & - & 2 & 4 & 3 & 14 \\
\hline Myxomycota (5) & - & - & - & - & - & - & - & - & - & - & 6 & 4 \\
\hline \multicolumn{13}{|l|}{$\begin{array}{l}\text { Decaying wood } \\
\text { without fungal }\end{array}$} \\
\hline fruiting bodies & 2 & 3 & 4 & 14 & 4 & 17 & 15 & 14 & 6 & 4 & 18 & 102 \\
\hline Soil and litter & - & - & - & - & - & 1 & - & 2 & 5 & 3 & 3 & 16 \\
\hline \multicolumn{13}{|l|}{ Emergence traps: } \\
\hline Over dead wood (-) & 6 & 3 & 1 & 10 & 11 & 32 & 27 & 39 & 11 & 53 & 66 & 260 \\
\hline Without dead wood (-) & 1 & 3 & - & 3 & 9 & 6 & 6 & 12 & 2 & 4 & 4 & 50 \\
\hline
\end{tabular}

At the moment of writing, taking into account about fifty species that have been added to the European fungus gnat fauna after 2004, a real percentage of the species with known larval microhabitats is a bit lower. Nevertheless, these values show a considerable increase in the level of knowledge in comparison to calculations in Jakovlev (1994) where numbers of fungus gnat species with known larval microhabitats (after deleting doubtful records and species that were later synomized) are ca 300 species in the Palaearctic region and ca 270 species in Europe (ca 230 species for Mycetophilidae, 21 for Bolitophilidae, 16 for Keroplatidae, 3 for Diadocidiidae and 2 for Ditomyiidae).

The percentage of species with known larval microhabitats varies from $30-40 \%$ for groups chiefly associated with dead wood and bark-encrusting fungi (family Keroplatidae, subfamilies
Gnoristinae and Leiinae) to $45-58 \%$ for groups chiefly reared in/on fruiting bodies (family Bolitophilidae, subfamilies Mycomyinae, Sciophilinae, tribes Exechiini and Mycetophilini). This reflects the better knowledge of the species inhabiting fungal fruiting bodies in comparison with those that do not necessarily live in fruiting bodies. The smallest groups, families Diadocidiidae (including Sciarosoma), Ditomyiidae and subfamily Manotinae that include only a few species in Europe comprise, most likely, only species associated with dead wood and woodgrowing fungi.

Numbers of species of different groups of macrofungi and other media from which fungus gnats have ever been reared in Europe are presented in Table 4. A list of recorded fungal hosts cover a total of ca 650 species of macrofungi including a wide range of systematic and ecological 
groups, like epigeic and wood-growing agarics, boletes, russulas, puffballs, hydnums, ramarioid, clavarioid species, polypores, corticeous, tremelloid species, saprotrophic and lignicolous Ascomycotina and slime moulds. The accumulated numbers of known fungal host species presented in Table 4 are calculated very approximately because different authors in different times and countries often used synonyms or indicated only fungal host genera.

There are also numerous rearing records from larvae collected under bark, in decaying wood, soil and litter without indication of fungal host species. Finally, rearing records obtained with emergence traps placed over dead wood or on soil, litter and ground vegetation, usually without indication of fungal hosts (Jakovlev et al. 1994, Irmler et al. 1996, Økland 1999, Ševčík \& Roháček 2008, Jakovlev et al. in prep.) are summarized in separate rows. This summary classifying the present knowledge of the larval microhabitats of fungus gnats allows several conclusions and speculations.

\subsubsection{Basidiomycete fungi with soft large fruiting bodies, mainly terrestrial}

As it was expected, most of the known fungal hosts belong to macrofungi with soft fleshy fruiting bodies with a cap and stipe, including members of Agaricales, Boletales and Russulaceae in Russulales that formerly were united in the order Agaricales s.l. but are now divided into different orders. They comprise, altogether ca 460 species, of these about 300 species of Agaricales (ca 240 epigeic and ca 60 lignicolous species), ca 70 species of Boletales and ca 90 species of Russulaceae. These fungi possess a considerable fungus gnat fauna and the main groups exploiting them are Bolitophilidae and Mycetophilidae, particularly Mycetophilini and Exechiini. In the Bolitophilidae most of the species are associated with fungi of the orders Agaricales and Boletales, while Mycetophilini and Exechiini frequently colonize Russulaceae as well.

In contrast, other subfamilies of Mycetophilidae generally avoid colonizing soft macrofungi. There are only a few exceptions like Coelophthinia thoracica (Winnertz, 1863), several species of Sciophila, (Sciophilinae), Coelosia tenella Zetterstedt, 1852 (Gnoristinae), Leia bimaculata Meigen, 1804, L. winthemii (Lehmann, 1822) and Rondaniella dimidiata (Meigen, 1804) (Leiinae), that have been repeatedly reared from agarics and Pezizales. Some of them, e.g. Sciophila species, retain their typical habit to live on the surface of fruiting bodies in slimy webs. Keroplatidae, Diadocidiidae, Ditomyiidae, and Manotinae are chiefly or exclusively absent in soft macrofungi.

Fungi of the order Agaricales (agarics) are exploited by the greatest variety of fungus gnats. In total 119 fungus gnat species have been reared from epigeic agarics and 104 species from agarics growing on wood. It can be supposed that fungus gnat larvae occur in almost all species of these fungi, regardless of size and place of occurrence of the fruiting bodies. In accordance with the hypothesis of the prevalence of polyphagy, fungus gnat species associated with agarics are, as a rule, polyphagous associated with several phylogenetically unrelated fungal hosts whereas specialized species could be exemplified with singletons like Bolitophila melanoleuci Polevoi, 1996 which has been reared only from fungi of the genus Melanoleuca, Rymosia batava Barendrecht, 1938 - from Inocybe, and Mycetophila finlandica Edwards, 1913 - from Tricholomopsis. A group of specialized species of the genus Brachypeza are confined to Pleurotus that has unclear systematic position but is similar to wood-growing agarics in texture of fruiting bodies.

Boletales, including the soft pore fungi of families Boletaceae (Boletus, Leccinum), Suillaceae (Suillus), Gyroporaceae (Gyroporus) and related families (Gomphidiaceae, Hygrophoraceae, Paxillaceae) that have gills under their caps but belong to the same order, have a rich fungus gnat fauna mainly similar with those of the agarics. Altogether 97 species of fungus gnats were reared from these fungi and the most specialized fauna are characterized for the genus Suillus. This differs clearly from other boletes by very high infestation of fruiting bodies by Bolitophila rossica and Exechiopsis indecisa that was a reason to suspect polyphyletic origin of the family Boletaceae (Jakovlev 1980).

Fungi of the family Russulaceae serve as hosts for 83 species of fungus gnats reared from 
ca 90 species of russulas (genus Russula) and milk-caps (Lactarius). The majority of them belong to subfamily Mycetophilinae and the proportion of specialized species is higher than among members of Agaricales and Boletales. Several species of Cordyla: C. crassicornis Meigen, 1818, C. fasciata Meigen, 1830, C. flaviceps Staeger, 1840, C. fusca Meigen, 1804, C. murina Winnertz, 1863, C. nitens Winnertz, 1863, C. nitidula Edwards, 1925, Exechia: E. contaminata Winnertz, 1863, E. nigroscutellata Landrock, 1912, E. pseudocincta Strobl, 1910 and Mycetophila: M. blanda Winnertz, 1863, M. estonica Kurina, 1992, are chiefly or exclusively associated with Russula and Lactarius. Some species clearly prefer particular groups of milk-caps, e.g. Exechia pseudocincta, Mycetophila blanda, M. estonica-Lactarius-deliciosus group, while Exechia contaminata - Lactarius necator.

About twenty species of hydnums, ramarioid and clavarioid fungi (orders Cantharellales, Gomphales and Thelephorales) together are known as hosts of 34 fungus gnat species, with a few exceptions belonging to the family Mycetophilidae. Of these at least one species, Mycetophila hetschkoi is strictly confined to this group of fungi.

From puffballs (Lycoperdales) only nine species: Coelosia tenella, Docosia gilvipes Haliday, 1856, Allodiopsis gracai Ševčík \& Papp, 2003, A. pseudodomestica Lackschewitz, 1937, Brachypeza bisignata Winnertz, 1863, Cordyla murina, C. styliforceps (Bukowski, 1934), Rymosia pseudocretensis Burghele-Balacesco, 1972 and Trichonta venosa Staeger, 1840 were reared so far.

\subsubsection{Wood-growing basidiomycete fungi with tougher fruiting bodies}

Wood-growing fungi other than agarics harbour about the same large number of fungus gnats. To use the terms that are in general use among mycologists, wood-growing fungi could be roughly divided into polypores, corticeous fungi that are separated from polypores by non-poroid hymenial surface of fruiting bodies, jelly fungi with jelly-like fruiting bodies, and a group of woodgrowing Ascomycota.

Polypores comprise a polyphyletic group of basidiomycetous fungi, the spores of which de- velop in pores (excluding boleti, but including some lamellate species with hard fruiting bodies). As a substrate for development of fungus gnat larvae, all polypores from which fungus gnats have ever been reared could be categorised either as hard polypores (i.e. species with bark-encrusting fruiting bodies having a hard, woody texture) or soft polypores with relatively soft fruiting bodies, similar to wood-growing agarics in terms of consistency and duration.

The simplest calculations presented in Table 4 demonstrate that only a relatively small portion of the spectrum of species of polypores and ecologically similar fungal groups has been studied for their fungus gnat fauna so far. In total, fungus gnats were reared from ca 60 species of hard polypores, ca 30 species of soft polypores, ca 30 species of corticoid fungi, ca 10 species of jelly fungi, ca 10 species of wood-growing Ascomycota and six species of slime moulds. However, the species pool of fungus gnats associated with these fungi is very diverse. All families and subfamilies are present there, with especially high numbers of Mycomyinae, Sciophilinae and Mycetophilini while the Bolitophilidae and Exechiini are represented by only a few species associated with soft polypores.

Hard polypores present a range of genera, viz.: Abortiporus, Antrodia, Antrodiella, Bjerkandera, Ceriporia, Ceriporiopsis, Daedalea, Daedaleopsis, Datronia, Fomes, Fomitopsis, Ganoderma, Gloeophyllum, Gloeoporus, Hapalopilus, Heterobasidion, Hypodonthia, Inonotus, Lenzites, Oxyporus, Phellinus, Piptoporus, Pycnoporus, Rigidoporus, Skeletocutis, Steccherinum, Trametes, Trichaptum from which fungus gnats have been recorded. In total, 121 fungus gnat species were reared from ca 60 species of these fungi. The web spinners of the genera $M y$ comya and Sciophila and the free living as larvae Dynatosoma and Mycetophila are the most diverse. Species with the restricted choice of their fungus hosts are recorded for the most common bracket fungi as Fomes fomentarius (Keroplatus tipuloides, Sciophila rufa), Fomitopsis pinicola (Mycetophila attonsa), Hyphodontia (Tetragoneura sylvatica) and Trichaptum (Trichonta flavicauda).

The category "Soft polypores" in the Table 4 includes both true polypores, including the gene- 
ra Amylocystis, Climacocystis, Fistulina, Grifola, Laetiporus, Meripilus, Neolentinus, Physisporinus, Polyporus, Postia, Rhodonia, Sparassis, Trechispora, Tyromyces and also some members of the order Russulales (genera Albatrellus, Hericium and Lentinellus) that are not phylogeneticaly related to polypores but similar in texture of fruiting bodies. Currently 72 fungus gnat species have been reared from ca 30 species of these fungi. Some are restricted to certain hosts, e.g. Bolitophila rectangulata - to Laetiporus sulphureus, B. aperta - to Amylocystis, Leptoporus and Postia; Mycetophila bialorussica and M. cingulum - to Polyporus; Trichonta brevicauda - to Lentinellus; Trichonta flavicauda - to Trichaptum; Dynatosoma thoracicum - to Postia caesia.

Wood-growing non-polyporous fungi with a few exceptions had not previously been the subject of rearing studies. However, they comprise a good place to find larvae of certain fungus gnat species. At the moment rearing records of fungus gnats have been recorded from the genera Asterodon, Bondarzewia, Byssomerulius, Chondrostereum, Coniophora, Corticium, Cylindrobasidium, Laxitextum, Leucogyrophana, Merulius, Mycoacia, Peniophora, Phlebia, Plicaturopsis, Resinicium, Scytinostroma, Serpula and Tulasnella. These fungi are analogous to bark-encrusting polypores in their environmental requirements, consistency of fruiting bodies and in associated fungus gnat fauna as well. They are chiefly colonized by web-spinners, both Keroplatidae (genera Cerotelion, Rocetelion, Keroplatus and Orfelia) and Mycetophilidae (Mycomya, Neoempheria, Leptomorphus, Phthinia, Sciophila, Syntemna, Apolephthisa, Ectrepesthoneura). Besides them there are rearing records for several species of Leiinae (Rondaniella) and Mycetophilinae (some Dynatosoma, Mycetophila, Phronia, Trichonta, Pseudorymosia and Synplasta) with free-living larvae. The existing data are generally not sufficient to reveal specialised fungus gnat species, but Diadocidia ferruginosa and Trichonta subterminalis were repeatedly reared only from these fungi.

Jelly fungi incorporate the five genera: Auricularia, Calocera, Exidia, Sebacina and Tremel$l a$, from which in total 25 species of fungus gnats have been reared. Of these eight species with larvae developing in webs, Cerotelion striatum
(Gmelin 1790), Keroplatus testaceus, Mycomya marginata, M. sigma Johannsen, 1910, Neoempheria striata, Sciophila hirta, S. nonnisilva and, S. plurisetosa Edwards, 1921 were reared from $\mathrm{Au}$ ricularia auricula-judae and one species, Leia bimaculata (Meigen, 1804) - from Calocera visco$s a$. Species that develop without webs like Docosia, Allodia, Anatella, Rymosia, Mycetophila, Phronia and Trichonta were reared from Tremella, Sebacina, Calocera and Exidia. None of the species have been reared with sufficient frequency to be certain that they are restricted to certain hosts though the first rearing records of Trichonta apicalis Strobl, 1898 and Phronia siebeckii Dziedzicki, 1889 from Calocera by Buxton (1960) were subsequently confirmed by Trifourkis (1977), Chandler (1978) and Sevcik (2006).

\subsubsection{Ascomycete fungi and slime moulds}

Among Ascomycotina fungus gnats use a relatively small number of species for development that might reflect the fact that they have not been enough investigated. From tough lignicolous Ascomycotina only 14 species of fungus gnats have been reared; Symmerus annulatus (Meigen, 1830) (Hypoxylon), Neoplatyura flava (Daldinia), Docosia gilvipes (Ustulina), Rondaniella dimidiata (Hypoxylon), Allocotocera pulchella (Curtis, 1837) (Daldinia), Sciophila hirta (Bulgaria), Sciophila lutea (Kretzchmaria), Mycetophila luctuosa (Kretzchmaria, Ustulina), M. marginata (Bulgaria), M. ocellus (Hypocrea, Kretzchmaria), Zygomyia vara (Encoenia), Anatella flavomaculata (Cydoniella), Anatella lenis and Stigmatomeria crassicornis (Ascocoryne).

Ascomycotina of the order Pezizales with big soft fruiting bodies growing on soil or on well-decayed wood remains (genera Aleuria, Gyromitra, Discina, Peziza, Verpa) support, in total, 34 fungus gnat species chiefly belonging to Exechiini, Sciophilinae and Leiinae. Several species of Allodia (Brachycampta) and Sciophila clearly prefer to colonise these fungi.

Slime moulds or myxomycetes have a very limited but strictly specialised fungus gnat fauna. Two species of the genus Platurocypta: P. punctum Stannius, 1831, P. testata Edwards, 1925 and two species of Mycetophila: M. adumbrata and $M$. vittipes were repeatedly reared from slime 
moulds of the genera Arcyria, Lycogala, Mycilago, Reticularia and Tubifera but never occurred in fungi. Manota unifurcata Lundström, 1913, the unique species of the subfamily Manotinae in Europe has been reared from rotten wood bearing an undetermined myxomycete (Chandler 1978) but there are three additional records from Russia and Finland, one from the surface of very moist, rotten birch wood covered with a grayish coat of an unidentified fungus (Zaitzev 1990), another from decaying alder bearing dead fruiting bodies of Fomitopsis pinicola (Jakovlev et al. 2006) and the third obtained with emergence trap over fallen aspen trunk bearing Trametes ochracea, Ganoderma lipsiense and Tomentella crinalis (Jakovlev, J., Penttinen, J., Polevoi, A., Salmela, J. \& Ståhls-Mäkelä, G., in prep.) where slime moulds were either unrecorded or absent.

\subsubsection{Dead wood impregnated with fungal mycelia}

This is a very important development site for certain fungus gnat species that are not necessarily associated with fruiting bodies. Currently a total of 102 species have been reared from larvae found in decaying wood impregnated with fungal mycelia or under bark without indication of fruiting bodies. It may be expected that many more species of fungus gnats with unknown larval microhabitats are associated with these substrates, still overlooked in comparison with soft macrofungi. Fungal mycelia in dead wood could serve as larval nutrition for a longer period after fruiting bodies dry out.

A pool of species reared from decaying wood covered with fungal mycelia incorporates all groups of fungus gnats (though records for Bolitophilidae and Exechiini most probably reflect pupation place) and the ratio between different taxa is relatively similar with those found in wood-growing fungi. The number of Keroplatidae, especially Macrocerinae species, obtained from dead wood is higher than those obtained from wood-growing fungi that could reflect the carnivorous diet of some keroplatids. Among Mycetophilidae only Gnoristinae that, according to Zaitzev (1979), could live in old galleries burrowed by other insects, are more diverse in dead wood than in fungal sporophores.
Finally, the very large total of 260 fungus gnat species that have been obtained with emergence traps over dead wood may indicate that at least part of them use it as a development site. This may concern all records of the species that live as larvae in webs (Diadocidiidae, Keroplatidae, Mycomyinae, Sciophilinae, some Gnoristinae and Leiinae) or within decaying wood (some Gnoristinae) and species with larvae protected with a shelter (Epicypta, some Phronia and Trichonta). For instance, using emergence traps has obtained eleven species of Macrocera whereas only four species have been reared using traditional methods. I also believe that some Mycetophilinae, e.g. members of the genera Anatella, Brevicornu, Zygomyia, Sceptonia and some species of Exechiopsis and Mycetophila, that have never been reared from fungal fruiting bodies but were obtained with emergence traps, develop in dead wood where they feed on wood-decaying fungi.

On the other hand, emergence traps could produce many species that do not actually breed in decaying wood but may use it as a cover during pupation stage. This may concern records obtained from dead wood samples of members of the Bolitophilidae and those species of the Exechiini and Mycetophilini that are well known as inhabitants of soft fruiting bodies of agarics. Even traditional rearing methods based on handpicking of the larvae found under bark could produce such species as Bolitophila cinerea, Exechia separata, Mycetophila fungorum and M. luctuosa (Wallace 1953) that develop within fruiting bodies and usually leave when fully fed.

\subsubsection{Soil, litter, moss carpets and other debris containing fungal mycelia}

At least 16 fungus gnat species have been recorded from these media. Again, among species that were found by Hackman (1963) in the burrows of voles, some Mycetophilinae, viz.: Cordyla fasciata, Exechiopsis fimbriata, Mycetophila fungorum, M. luctuosa are, most probably irrelevant to this development site, but migrated there for pupation. Other species like Mycomya nitida and Docosia gilvipes also recorded by Hackman (1963) may develop there, as well as Docosia fumosa Edwards, 1925, Leia bilineata and L. piffardi found in bird nests (Edwards 1925, Hutson 
et al. 1980, Rulik \& Kallweit 2006). Speolepta leptogaster larvae live in silky webs on the walls of caves and feed mainly on algae and other organisms there (Matile 1962).

Specialization to develop in media other than dead wood and wood-growing fungi may be also supposed for some keroplatids like Neoplatyura flava, Pyratula zonata and several species of Macrocera that have repeatedly been obtained in emergence traps on soil and ground vegetation.

Acknowledgements. Sincere thanks are given to the Finnish mycologists, Heikki Kotiranta (Finnish Environment Institute) who kindly identified all corticeous fungi, Tuomo Niemelä and Dmitry Schigel (Botanical Museum, Helsinki University) - polypores, and Esteri Ohenoja (Oulu University) who has advised on fungal nomenclature. The author is very grateful to Peter Chandler (Melksham, UK) and the anonymous referee for their revisions and comments to the manuscript. Special thanks are due to Juha Siitonen (Finnish Forest Research Institute) who has advised and helped to arrange the project aimed on rearing from previously unknown fungus species and substrates. Gergely Várkonyi (Finnish Environment Institute, Friendship Park Research Centre, Kuhmo, Finland) and Dmitry Schigel are thanked for putting their materials at my disposal. Finnish Expert Group for Diptera is thanked for financial support with publication costs. This paper is a part of the project "Finnish fungus gnats (Diptera, Mycetophilidae, etc.): faunistics, habitat requirements and threat status". The financial support in 2003-2007 from the Finnish Ministry of Environment is hereby acknowledged.

\section{References}

Alexander, K. N. A. 2002: The invertebrates of living and decaying timber In Britain \& Ireland - a provisional annotated checklist. - English Nature Research Reports. No. 467, English Nature, Peterborough. 142 pp.

Barendrecht, G. 1938: The Dutch Fungivoridae in the collection of the Zoological Museum of Amsterdam. Tijdschrift voor Entomologie 38: 35-54.

Bechev, D. 1989: Larvae of Mycetophiloidea (Diptera) found in fungi in Bulgaria. - Proceedings of the State Plovdiv University "Paisij Khilebdarsky": Biology" 6: 161-162. Plovdiv.

Bechev, D. 2000: World distribution of the genera of fungus gnats (Diptera: Sciaroidea, excluding Sciaridae). Studia dipterologica 7: 543-552.

Beling, Th. 1875: Beitrag zur Metamorphoze zweiflügeliger Insekten. - Archiv Für Naturgeschichte 41: 3157.

Bogatyreva, L. A. 1979a: (New data on the species composition of insects colonising fungi in coniferous forests of the West Siberian taiga zone). - Tomsk. VINITI, N3509-79. Received 08.10.1979. P. 1-5. [In Russian.]
Bonnamour, S. 1926: Les insectes parasites des champignons. 2. Elevages et nouvelle liste de Diptères fungicoles. - Annales de la Societe Linneenne de Lyon. Lyon, Paris. 72: 85-93.

Brocher, F. 1931: Observations biologiques sur la larve du Delopsis aterrima Zett. et sur celle du Leptomorphus walkeri Curt. (Diptères mycétophiles). — Revue suisse de zoologie 38: 67-76.

Buxton, P. A. 1960: British Diptera associated with fungi.3. Flies of all families reared from about 150 species of fungi. - Entomologist's Monthly Magazine 96: 61-94.

CABI, Bioscience databases 2008 - [WWW document]. URL http://www.indexfungorum.org (Site visited 28 May 2010 as version 1.3 of April $19^{\text {th }} 2007$ ).

Canzanelli, A. 1941: La fauna dei funghi freschi. 2. Contributo: La Dipterofauna Fungicola. - Commentationes. Vol.5. N3: 211-282.

Cardew, M. \& Carrières, E. 2001: First Record of Keroplatus tipuloides (Bosc, 1792) in Luxembourg (Diptera, Nematocera, Keroplatidae). - Bulletin de la Société des sciences naturelles du Grand-Duché de Luxembourg 101: 111-116.

Chandler, P. J. 1978: Associations with plants. Fungi. In: Stubbs, A. \& Chandler, P.J. (eds.), A dipterist's handbook: 199-211. The Amateur Entomologist's Society. Middlesex. 255 pp.

Chandler, P. J. 1981: The European and North American species of Epicypta Winnertz (Diptera: Mycetophilidae). - Entomologica Scandinavica 2: 199-212.

Chandler, P. J. 1987: Notes on British fungus gnats of the smaller families and subfamilies (Diptera, Mycetophiloidea). - Proceedings of the British Entomology \& Natural History Society 20: 105-118.

Chandler, P. J. 1993a: New rearing records of fungus gnats (Diptera: Mycetophilidae and allied families). - Dipterist's Digest (Second series) 13: 29-35.

Chandler, P. J. 1993b: Keroplatus testaceus Dalman (Dipt., Keroplatidae) new to Scotland and other notes. - Entomologist's Monthly Magazine 129: 61-65.

Chandler, P. J. 2004: Fauna Europaea: Mycetophilidae. In: de Jong, H. [ed.], Fauna Europaea Diptera, Nematocera. Fauna Europaea, version 1.3. [WWW document]. URL http://www.faunaeur.org (Site visited 7 May 2010 as version 1.3 of April $19^{\text {th }} 2007$ )

Chandler, P. J. 2009: The fungus gnats (Diptera: Bolitophilidae, Keroplatidae, Mycetophilidae) of Sardinia, with description of six new species. - Zootaxa 2318: 450 506.

Chandler, P. J. 2010: Fungus Gnats Recording Scheme. Newsletter 3. Autumn 2009. 4 p.

Chandler, P. J. \& Pijnakker, J. 2009: Tropical fungus gnats established in nurseries in the Netherlands (Diptera: Keroplatidae and Mycetophilidae). — British Journal of Entomology \& Natural History 22: 81-93.

Cheetham, C. A. 1920: A liverwort-eating larva. — Naturalist. P.190.

Dely-Draskovits, Á. 1974: Systematische und ökologische Untersuchungen an den in Ungarn als Schädlinge der Hutpilze aufretenden Fliegen. 6. Mycetophilidae 
(Diptera). - Folia entomologica Hungarica 27: 2941.

Dufour, L. 1842: Histoire des métamorphoses du Sciophila striata. - Mémoires de la Société des Sciences et des Arts de Lille 1841: 201-207.

Edwards, F. W. 1925: British Fungus-Gnats (Diptera, Mycetophilidae). With a revised Generic Classification of the Family. - Transactions of the Entomological Society of London. 1924: 505-670.

Eisfelder, I. 1955: Die häufigsten Pilzbewohner. — Zeitschrift für Pilzkunde. Bd.18, H.1. S.1-5; Bd.19, H.1, S. 12-20.

Enslin, E. 1906: Die Lebensweise von Macrocera fasciata MEIG. - Zeitschrift für Wissenschaftliche Insektenbiologie 2: 251-253.

Falcoz, L. 1921: Notes sur divers insectes fongicoles. Miscellània Entomologica 25: 57-62.

Falcoz, L. 1923: Observations biologiques sur divers insectes des environs de Vienne en Dauphiné (2e note). - Bulletin de la Société Entomologique de France 28: 261-263.

Falcoz, L. 1926: Observations biologiques sur divers insectes des environs de Vienne en Dauphiné (5e note). - Bulletin de la Société Entomologique de France 32: 130-134.

Falk, S. J. \& Chandler, P. J. 2005: A review of the scarce and threatened flies of Great Britain. Part 2: Nematocera and Aschiza not dealt with by Falk (1991). Species status 2: 1-189. - Joint Nature Conservation Committee, Peterborough.

Gagné, R. J. 1981: A Monograph of Trichonta with a model for the distribution of Holarctic Mycetophilidae (Diptera). - United States Department of Agriculture, Technical Bulletin. 1638: 1-64.

Hackman W. 1963: Studies on the dipterous fauna in burrows of voles (Microtus, Clethrionomus) in Finland. - Acta Zoologica Fennica 102: 1-64.

Hackman, W. \& Meinander, M. 1979: Diptera feeding as larvae in macrofungi in Finland. - Annales Zoologici Fennici 16: 50-83.

Hanski, I. 1989: Fungivory: Fungi, Insects and Ecology. In: Wilding, N. (ed.), Insect-fungus interactions: 2568. Academic Press, London.

Heikinheimo, O. \& Raatikainen, M. 1971: Paikan ilmoittaminen Suomesta talletetuissa biologisissa aineistoissa. (The recording of locations of biological finds in Finland). - Annales Entomologici Fennici 37(1a): 1-30. [In Finnish with English summary.]

Hutson, A. M., Ackland, D. M. \& Kidd, L. N. 1980: Mycetophilidae (Bolitophilinae, Ditomyiinae, Diadocidiinae, Keroplatinae, Sciophilinae and Manotinae). Handbooks for the Identification of British Insects 9: 1-111. Royal Entomological Society of London.

Irmler, U., Heller, K. \& Warning, J. 1996: Age and tree species as factors influencing the populations of insects living in dead wood (Coleoptera, Diptera: Sciaridae, Mycetophilidae). - Pedobiologia 40: 134-148.

Jakovlev, E. B. 1980: (Diptera associated with macrofungi of the family Boletaceae in Karelia). — In: Shubin V.I. (ed.) Mykorrhizal fungi and mykorrhizae of main fo- rest tree species in Karelia. Karelian Branch of USSR Academy of Sciences. Petrozavodsk: 36-45. [In Russian.]

Jakovlev, E.B. 1986: (Mycetobiontic insects of Karelia [ecologo-faunistical list]). — In: Jakovlev, E.B. \& Uzenbajev, S.D. (eds.) Fauna and ecology of arthropods of Karelia. Karelian Branch of USSR Academy of Sciences. Petrozavodsk: 83-123. [In Russian.]

Jakovlev, E.B. 1993: Mushrooms and insects associated with them in Petrozavodsk city parks. - Aquilo, ser. Botany 31: 131-136.

Jakovlev, E. B.1994: Palearctic Diptera associated with fungi and myxomycetes. - Karelian Research Center, Russian Academy of Sciences, Forest Research Institute, Petrozavodsk. 127 pp. [In Russian with English summary.]

Jakovlev, E. B.1995: Species diversity and abundance of fungivorous Diptera in forests and city parks of Russian Karelia. - An International Journal of Dipterological Research 6: 335-362.

Jakovlev, E. B., Polevoi, A. V. \& Humala, A. E. 1994: (Insects reared from soil samples in Vaccinium pine stand). - In: Zjabchenko, S. S. \& Fedorets, N. G. (eds.), Structural and functional organisation of forest soils in mid-taiga subzone of Karelia. Karelian Research Center of the Russian Academy of Science, Petrozavodsk. Pp. 128-145. [In Russian.]

Jakovlev, J., Kjærandsen, J. \& Polevoi, A. 2006: Seventy species of fungus gnats new to Finland (Diptera: Mycetophilidae). - Sahlbergia 11: 22-39.

Jakovlev, J. \& Penttinen, J. 2007: Boletina dispectoides sp.n. and six other species of fungus gnats (Diptera: Mycetophilidae) new to Finland. - Entomologica Fennica 18: 211-217.

Jakovlev, J. \& Polevoi, A. 2008: Two new species of the genus Phronia Winnertz (Diptera: Mycetophilidae) from Finland and Russian Karelia. - Entomologica Fennica 19: 199-206.

Jonsell, M. \& Nordlander, G. 2004: Host selection patterns in insects breeding in bracket fungi. - Ecological Entomology 29: 697-705.

Kjærandsen, J., Hedmark, K., Kurina, O., Polevoi, A., Økland, B. \& Götmark, F. 2007: Annotated checklist of fungus gnats from Sweden (Diptera: Bolitophilidae, Diadocidiidae, Ditomyiidae, Keroplatidae and Mycetophilidae). - Insect Systematics and Evolution Supplements 65:1-128.

Khalidov, A. B. 1984: (Insects - destroyers of fungal fruiting bodies). - Kazan State University. Kazan. 151 p. [In Russian.]

Komonen, A. 2001: Structure of insect communities inhabiting old-growth forest specialist bracket fungi. Ecological Entomology 26: 63-75.

Kotiranta, H., Saarenoksa, R, \& Kytövuori, I. 2009: Aphyllophoroid fungi of Finland. A check-list with ecology, distribution and threat categories. - Norrlinia 19:1-223.

Krivosheina, N. P., Zaitzev, A. I. \& Jakovlev, J. B. 1986: (Insects - destroyers of macrofungi in forests of the European part of USSR [including identification keys 
and figures for some groups of fungus gnats]). - Nauka, Moscow. 309 p. [In Russian.]

Krivosheina, N. P. \& Mamajev, B. M. 1967: (Key to the the larvae of wood-inhabiting dipteran insects). - Nauka, Moskow. 287 p. [In Russian.]

Kurina, O. 1991: Mycetophilidae (Diptera) reared from macrofungi in Estonia. - Proceedings of the Estonian Academy of Sciences. Biologia 40:84-90.

Kurina, O. 1994: New records of Mycetophilidae (Diptera) reared from macrofungi in Estonia. - Proceedings of the Estonian Academy of Sciences. Biologia 43: 216220.

Kurina, O. 1998: Fungus gnats in Estonia (Diptera: Bolitophilidae, Keroplatidae, Macroceridae, Ditomyiidae, Diadocidiidae, Mycetophilidae). - Dissertationes Biologicae Universitatis Tartuensis. Vol.38. Tartu University Press. 107 p.

Landrock, K. 1927: Fungivoridae (Mycetophilidae). — In: Lindner, E. (ed.), Die Fliegen der Palaearktischen Region. 8: 1-196. E. Schweizerbart, Stuttgart.

Landrock, K. 1940: Zweiflüger oder Diptera. VI: Pilzmücken oder Fungivoridae (Mycetophilidae). - In: Dahl, F. (ed.), Die Tierwelt Deutschlands, 38: 1-166. Jena.

Laštovka, P.1972: Předběžna ekologiská klassificace čeledi Mycetophilidae (Diptera). Preliminary ecological classification of the family Mycetophilidae (Diptera). - Sbornic Lihočeskogo. Muz. Česke budejovice. Přirodny vědy. 12: 91-93. [In Czech.]

Madwar, S. 1937: Biology and morphology of the immature stages of Mycetophilidae. - Philosophical Transactions of the Royal Society. London. Series B. Vol. 227: 1-110.

Mansbridge, G. H. 1933: On the biology of some Ceroplatinae and Macrocerinae (Diptera, Mycetophilidae). With an appendix on the chemical nature of the web fluid in larvae of Ceroplatinae by H.W. Buston. Transactions of the Royal Entomological Society of London 81: 75-92.

Martinsen, L. \& Søli, G. E. E. 2000. Description of three species of Ectrepesthoneura Enderlein (Diptera, Mycetophilidae). - Norwegian Journal of Entomology 47: 137-147.

Matile, L. 1962: Morphologie et biologie d'un Diptère cavernicole Speolepta leptogaster Winnertz. - Mémoires du Muséum national d'Histoire naturelle sér. A, Zool. 20: 219-242.

Matile, L. 1963: Un Diptère Mycetophilidae nouveau. Bulletin de la Société Entomologique de France, 68: 40-44.

Matile, L. 1964: Diptères Fungivoridae récoltés dans l'Ile de Port-Cros (Var). - Cahiers des Naturalistes, Bulletin des Naturalistes Parisiens, nouvelle série 20: 510.

Matile, L. 1990. Recherches sur la systématique et l'evolution des Keroplatidae (Diptera, Mycetophiloidea). Mémoires du Muséum national d'Histoire naturelle sér. A, Zool. 148: 1-682.

Matile, L. 1997. Phylogeny and evolution of the larval diet in the Sciaroidea (Diptera, Bibionomorpha) since the mesozoic. - Mémoires du Muséum national d'Histoire naturelle 173: 273-303.

Okada, I. 1939: Studien über die Pilzmücken (Fungivoridae) aus Hokkaido (Diptera, Nematocera). — Journal of the Faculty of Agriculture, Hokkaido Imperial University. Sapporo 49: 267-336.

Økland, B. 1999: New rearing records of forest-dwelling Diptera. - An International Journal of Dipterological Research 10: 133-146.

Ostroverkhova, G. P. 1979: (Fungus gnats [Diptera, Mycetophiloidea] of Siberia). - Tomsk University, Tomsk: 308 pp. [In Russian.]

Parmenter, L. 1953: On the breeding of Mycomya marginata Mg. - Journal of the Society for British Entomo$\operatorname{logy}$ 4: 124.

Plachter, H. 1979a: Zur Kenntnis der Präimaginalstadien der Pilzmücken (Diptera, Mycetophiloidea). Teil 1: Gespinstbau. - Zoologische Jahrbücher, Abteilung für Anatomie und Ontogenie 101: 168-266.

Plachter, H. 1979b: Zur Kenntnis der Präimaginalstadien der Pilzmücken (Diptera, Mycetophiloidea). Teil 2: Eidonomie der Larven. - Zoologische Jahrbücher, Abteilung für Anatomie und Ontogenie 101:271-392.

Plassmann, E. 1971: Über die Fungivoriden Fauna (Diptera) des Naturparkes Hoher Vogelsberg. — Oberhessische Naturwissenschaftliche Zeittschrift 38: 53-87.

Ribeiro, E. 1990: Contribution to the study of Fungusgnats (Diptera, Mycetophiloidea of Portugal. II. Seven new records. - Boletim da Sociedade Portuguesa de Entomologia 4: 173-194.

Rimšaite, J. 2000: Contribution to the knowledge of insects humificators of fungi in Lithuania. - Acta Zoologica Lituanica 10: 95-99.

Rotheray, G. E., Hancock, G., Hewitt, D., Horsfield, D., MacGowan, I., Robertson, D. \& Watt, K. 2001: The biodiversity and conservation of saproxylic Diptera in Scotland. - Journal of Insect Conservation 5: 77-85.

Rulik, B \& Kallweit, U. 2006: A blackbird's nest as breeding substrate for insects - first record of Docosia fumosa Edwards, 1925 (Diptera: Mycetophilidae) from Germany. - Studia dipterologica 13: 41-42.

Sakharova, A. V. 1977: On the fauna of fungus-gnats (Diptera, Mycetophilidae) of Moscow district. - Entomologicheskoje Obozrenie 56, 1: 71-78. [In Russian with English summary.]

Sasakawa, M. \& Ishizaki, H. 1999: Fungus gnats of the genera Exechiopsis Tuomikoski and Pseudexechia Tuom. in Japan (Diptera: Mycetophilidae). — Entomological science 2: 147-156.

Schiegg, K. 1999: Limiting factors of saproxylic insects: habitat relationships of an endangered ecological group. — PhD thesis, Swiss Federal Institute of Technology, Zurich. 84 pp.

Schigel, D., Niemelä, T. \& Kinnunen, J. 2006: Polypores of western Finnish Lapland and seasonal dynamics of polypore beetles. - Karstenia 46: 37-64.

Ševčík, J. 2006: Diptera associated with fungi in the Czech and Slovac Republics. — Časopis Slezského zemského muzea, Série A, Vìdy prírodní (Opava) 55 [supplement 2]: 1-84. 
Ševčík, J. \& Roháček, J. 2008: Fungus gnats (Diptera: Mycetophilidae and Keroplatidae) reared from grass and sedge tussocks in the Czech Republic - C Casopis Slezského zemského muzea, Série A, Vìdy prírodní (Opava) 57: 175-178.

Smith, K. G. V. 1989: An introduction to the immature stages of British flies. - In: Dolling, W. R. \& Askew, R. R. (eds.), Handbooks for the Identification of British Insects. Vol. 10. Pt 14: 1-281.

Steenberg, C. M. 1924: Étudé sur deux espèces de Phronia dont les larves se forment de leurs excréments une couche protectrice la Phronia strenua et la Phronia johannae n.sp. (Diptera, Nematocera). — Videnskabelige Meddeleiser fra Dansk Naturhistoriske Forening $78: 1-51$

Steenberg, C. M. 1938: Récherches sur la metamorphose d'un Mycétophile Delopsis aterrima Zett. — Biologiske Meddeleiser Kongelige Danske Videnskabelige Selskabs 14: 1-29.

Trifourkis, S. 1977: The bionomics and taxonomy of the larval Mycetophilidae and other fungicolous Diptera. — North East London Polytechnic Ph.D. Thesis. University of London. Vol. I: Text: 1-393. Vol. II: Figures, tables and annexes: 394-793.

Tuomikoski, R. 1966: Generic taxonomy of the Exechiini (Dipt., Mycetophilidae). - Annales Entomologici Fennici 32: 159-194.

Väisänen, R. 1981: Is there more then one successional phase in the mycetophilid (Diptera) community feeding on a mushroom? - Annales Zoologici Fennici 18: 199-201.

Väisänen, R. 1984: A monograph of the genus Mycomya Rondani in the Holarctic region (Diptera, Mycetophilidae). - Acta Zoologica Fennica 177: 1-346.

Wallace, H. R. 1953: The ecology of the insect fauna of pine stumps. - Journal of Animal Ecology 22: 154171.

Winnertz, J. 1863: Beitrag zu einer Monographie der Pilzmucken. - Verhandllungen der Zoologish-Botanischen Gesellschaft in Wien. 13: 637-964.

Zaitzev, A. I. 1979: Xylophilous larvae of the subfamily Sciophilinae (Diptera, Mycetophilidae). — Entomologicheskoje Obozrenije 58, 4:861-869. [In Russian.]
Zaitzev, A. I. 1982: (Fungus gnats of the genus Sciophila Meig. of the Holarctic). - Moscow. 75 pp. [In Russian.]

Zaitzev, A. I. 1983: (The anatomy of the digestive system of the larvae of lower mycetophilids [Diptera, Mycetophiloidea] in relation of their trophival specialization.) - Biologicheskie Nauki. Ser Zoology. Vol. 4: 38-43. [In Russian.]

Zaitzev, A. I. 1984a: (Trends on the morphological specialization of digestive system of the larvae of higher mycetophilids [Diptera, Mycetophiloidea]). — Biologicheskie Nauki. Ser Zoology 1: 38-44. [In Russian.]

Zaitzev, A. I. 1984b: (Trends on the morphological specialization of the mouth parts of the larvae of mycetophiloid dipterans [Diptera, Mycetophiloidea]). - Biologicheskie Nauki. Ser Zoology 10: 38-45. [In Russian.]

Zaitzev, A. I. 1984c: (Complexes of mycetophiloid dipterans [Diptera: Mycetophiloidea] in forest biocenoses of Russian southern taiga). — Zhivotny mir juzhnoi taigi. Institute of Evolutional morphology and ecology of animals of the USSR Academy of Sciences. Moscow: 205-210. [In Russian.]

Zaitzev, A. I. 1990: (On the preimaginal stages of Manota unifurcata Lundst. and the systematic position of the subfamily Manotinae). — Biologicheskie Nauki. Ser Zoology 3: 63-71. [In Russian.]

Zaitzev, A.I. 1994: (Fungus-gnats [Diptera, Mycetophiloidea] of Russia and adjacent countries. Part I. Families Ditomyiidae, Bolitophilidae, Diadocidiidae, Keroplatidae, Mycetophilidae (subfamilies Mycomyinae, Sciophilinae, Gnoristinae, Allactoneurinae, Leiinae). — Nauka. Moscow. 288 p. [In Russian.]

Zaitzev, A. I. 2003: Fungus gnats (Diptera, Sciaroidea) of the fauna of Russia and adjacent regions. Part II. - An International Journal of Dipterological Research 14: 77-386.

Zaitzev, A. I. \& Ševčík, J. 2002: A review of the Palaearctic species of the Leptomorphus quadrimaculatus (Matsumura) group (Diptera: Mycetophilidae). — Acta Zoologica Hungarica 48: 203-211. 
Appendix

Names of fungi from which insects were reared in this investigation.

Basidiomycota. Agaricomycetes

Agaricales

- Armillaria mellea-complex.

- Hohenbuehelia petaloides (Bull.) Schulzer

- Hypholoma fasciculare (Huds.) P. Kumm.

- Pholiota squarrosa (Vahl) P. Kumm.

- Chondrostereum purpureum (Pers.: Fr.) Pouzar

- Cylindrobasidium laeve (Fr.) D.A. Reid

Boletales

- Leucogyrophana romellii (Fr.) Ginns

Gloeophyllales

- Gloeophyllum sepiarium (Wulfen : Fr.) P. Karst.

Polyporales

- Antrodia serialis (Fr.) Donk

- Antrodia xantha (Fr.: Fr) Ryvarden

- Antrodiella pallescens (=semisulpina) (Pilát) Niemelä \& Miettinen

- Antrodiella romellii (Donk) Niemelä

- Bjerkandera adusta (Willd.: Fr.) P. Karst.

- Byssomerulius corium (Pers.) Parmasto

- Datronia mollis (Sommerf.) Donk

- Fomes fomentarius (L.: Fr.) Fr.

- Fomitopsis pinicola (Sw.: Fr.) P. Karst.

- Ganoderma applanatum (G. lipsiense) (Pers.) Pat.

- Gloeoporus dichrous (Fr.: Fr.) Bres.

- Leptoporus mollis (Pers. Fr.) Quel.

- Merulius tremellosus Schrad.

- Neolentinus lepideus (Fr.) Redhead \& Ginns

- Phlebia radiata Fr.

- Phlebiopsis gigantea (Fr.) Jülich

- Physisporinus sanguinolentus (Alb. \& Schwein.) Donk 1966

- Polyporus melanopus (Pers.: Fr.) Fr.

- Postia alni Niemelä \& Vampola

- Postia caesia (Schrad.: Fr.) P. Karst.

- Postia stiptica (Pers.: Fr.) Julich.

- Pycnoporus cinnabarinus (Jacq.: Fr.) P. Karst.

- Rhodonia placenta (Fr.) Niemelä. K.H. Larsson \& Schigel

- Rigidoporus populinus (Schumach.: Fr.) Pouzar

- Skeletocutis amorpha (Fr.) Kotl. \& Pouzar

- Skeletocutis biguttulata (Romell.) Niemelä

- Sparassis crispa (Wulfen) Fr.

- Steccherinum luteoalbum (P. Karst.) Vesterh.

- Steccherinum nitidum (Pers.: Fr.) Vesterh.

- Trametes hirsuta (Wulfen) Lloyd
- Trametes ochracea (Pers.) Gilb. \& Ryvarden

- Trametes pubescens (Schumach.: Fr.) Pilát

- Trametes velutina (Pers.) G. Cunn.

- Trichaptum abietinum (Pers.: Fr.) Ryvarden

- Trichaptum pargamenum (Fr.) G. Cunn.

Basidiomycota. Incertae sedis

Auriculariales

- Exidia cartilaginea S. Lundell \& Neuhoff

- Exidia repanda Fr.

Cantharellales

- Hydnum repandum L.: Fr.

Hymenochaetales

- Asterodon ferruginosus Pat.

- Hyphodontia paradoxa (Schrad.) Langer \& Vesterh.

- Hyphodontia radula (Pers.) Langer \& Vesterh.

- Hyphodontia barba-jovis (Bull.: Fr.) J. Erikss.

- Inonotus radiatus (Sw.: Fr.) P. Karst.

- Phellinus conchatus (Pers.: Fr.) Quel.

- Phellinus tremulae (Bondartsev) Bondartsev \& Borisov

Russulales

- Laxitextum bicolor (Pers.: Fr.) Lentz

- Lentinellus vulpinus (Sowerby) Kühner \& Maire

- Peniophora laurentii S. Lundell

- Stereum subtomentosum Pouzar

- Stereum rugosum Pers.: Fr.

Trechisporales

- Trechispora hymenocystis (Berk. \& Broome) K.H. Larss.

Tremellales

- Tremella foliacea Pers.: Fr.

Incertae sedis

- Resinicium bicolor (Alb. \& Schwein.) Parmasto

Ascomycota

Helotiales

- Ascocoryne cylichnium (Tul.) Korf

- Encoelia fascicularis (Alb. \& Schwein.) P. Karst.

Pezizales

- Peziza badia Pers.

- Peziza succosa Berk

- Verpa bohemica (Krombh.) J. Schröt.

Slime moulds

- Lycogala epidendrum (J.C. Buxb. ex L.) Fr. 